\title{
Global semi-arid climate change over last 60 years
}

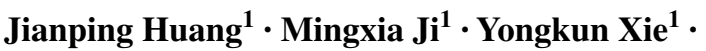 \\ Shanshan Wang ${ }^{1}$ Yongli $\mathrm{He}^{1} \cdot$ Jinjiang $\operatorname{Ran}^{1}$
}

Received: 19 November 2014 / Accepted: 29 April 2015 / Published online: 13 May 2015

(c) The Author(s) 2015. This article is published with open access at Springerlink.com

\begin{abstract}
This study analyzes areal changes and regional climate variations in global semi-arid regions over 61 years (1948-2008) and investigates the dynamics of global semiarid climate change. The results reveal that the largest expansion of drylands has occurred in semi-arid regions since the early 1960s. This expansion of semi-arid regions accounts for more than half of the total dryland expansion. The area of semi-arid regions in the most recent 15 years studied (1990-2004) is $7 \%$ larger than that during the first 15 years (1948-1962) of the study period; this expansion totaled $0.4 \times 10^{6}$ and $1.2 \times 10^{6} \mathrm{~km}^{2}$ within the American continents and in the Eastern Hemisphere, respectively. Although semi-arid expansion occurred in both regions, the shifting patterns of the expansion are different. Across the American continents, the newly formed semi-arid regions developed from arid regions, in which the climate became wetter. Conversely, in the continental Eastern Hemisphere, semi-arid regions replaced sub-humid/humid regions, in which the climate became drier. The climate change in drying semi-arid regions over East Asia is primarily dominated by a weakened East Asian summer monsoon, while the wetting of semi-arid regions over North America is primarily controlled by enhanced westerlies.
\end{abstract}

Electronic supplementary material The online version of this article (doi:10.1007/s00382-015-2636-8) contains supplementary material, which is available to authorized users.

Jianping Huang

hjp@1zu.edu.cn

1 Key Laboratory for Semi-Arid Climate Change of the Ministry of Education, College of Atmospheric Sciences, Lanzhou University, Lanzhou, Gansu, China
Keywords Semi-arid C Climate change - Expansion . Aridity index

\section{Introduction}

Semi-arid regions cover $\sim 15 \%$ of the Earth's land surface and supported $14.4 \%$ of the global population in the year 2000 (Safriel and Adeel 2005). The ecosystems in such regions are fragile and sensitive to strong interactions between human activities and climate changes (Charney 1975; Huang et al. 2010; Rotenberg and Yakir 2010; Xue 1996; Zeng et al. 1999). Most human effects on semi-arid climates are related to agricultural exploitation of lands. Introduction of agriculture into such areas, whose natural condition is already agriculturally marginal, might be motivated by a number of economic or social factors (Liu et al. 2008). These factors include the need to provide food for a larger population, the decreasing productivity of existing agricultural land, and the profit motive. Semi-arid populations rely primarily on rain-fed agriculture for their livelihoods, and fluctuations in precipitation greatly affect the availability of surface water resources that are necessary to sustain agricultural irrigation (Liu and Xia 2004; Schwinning et al. 2004). For instance, a slight shift in rainfall patterns or a temperature change could be disastrous. In addition, much of the arid and semi-arid land has undergone substantial anthropogenic change via urbanization and land-use changes (Gao et al. 2010; Li et al. 2012; Xu et al. 2011; Bounoua et al. 2009; Georgescu et al. 2009; Scanlon et al. 2006; Fricke et al. 2009). Thus, semi-arid climate change is important to investigate for the purposes of policy making.

The long-term global warming trend is particularly enhanced over semi-arid regions (Huang et al. 2012; Ji 
et al. 2014). Both observations and modeling studies indicate that in a warmer climate, droughts may become longer in duration and more severe in currently drought-prone regions because of enhanced evaporation and reduced precipitation (Dai 2013a). Drying trends may occur most significantly in semi-arid and arid regions as a result of global warming, leading to an intensification of the hydrological cycle, with climatologically wet regions becoming wetter and dry regions becoming drier (Chou et al. 2009; Held and Soden 2006; Seager et al. 2010). Recent climate model simulation shows that the area of global drylands is projected to expand by $\sim 10 \%$ by 2100 , except in India and northern tropical Africa, which will become wetter (Feng and Fu 2013). Decadal-scale climate anomalies and land surface degradation have also occurred in these regions (Dregne 2002), and the risk of land degradation is greatest in the middle of the aridity gradient, which is mostly located in semi-arid drylands (Safriel and Adeel 2005).

Although historical climate changes in semi-arid regions have been discussed in previous studies (Bader and Latif 2003; Giannini et al. 2003; Hoerling et al. 2006; Lu 2009; Lu and Delworth 2005; McCabe et al. 2008; Méndez and Magaña 2010; Zeng et al. 1999), most of these studies are regionally limited by focusing on a particular region or nation, i.e., Sahelian semi-arid regions (Hoerling et al. 2006; Lu and Delworth 2005); few studies emphasize global semi-arid areas. In this work, we study semi-arid climate change from a global perspective.

Three major questions are addressed in this study. Has expansion occurred in all semi-arid regions over the last 61 years? If so, the shifts of the semi-arid regions and other climate categories are important to understand. How has the aridity changed in these regions? What are the dynamics of global climate change in semi-arid regions? To understand the regional climate variability, this study conducts a systematic examination of areal changes in Sect. 4 and an assessment of climate change in semi-arid regions in Sect. 5. Section 6 illustrates the dynamics of semi-arid climate change globally, and the conclusions and discussion are presented in Sect. 7.

\section{Datasets and methodology}

\subsection{Observation data}

The precipitation dataset that we mainly used in this study is obtained from the National Centers for Environmental Prediction (NCEP) Climate Prediction Center (CPC) (Chen et al. 2002). It is typically labelled as the PRECipitation REConstruction over Land (PREC/L) dataset, and it is an observation station-based dataset with a globally covered $0.5^{\circ} \times 0.5^{\circ}$ latitude-longitude resolution for the period extending from 1948 to the present. The PREC/L is derived from gauge observations taken at over 17,000 stations, and it was collected from two large individual datasets: the Global Historical Climatology Network version 2 (GHCN2), and the Climate Anomaly Monitoring System (CAMS). Therefore, the PREC/L can be regularly updated in near real time with a sufficient number of stations and unique interpolation methods. The definition of drylands by precipitation is as follows: areas that experience annual precipitation $(\mathrm{P})$ of less than $500 \mathrm{~mm}$; drylands are further classified into hyperarid $(\mathrm{P}<25 \mathrm{~mm})$, arid $(25 \mathrm{~mm} \leq \mathrm{P}<250 \mathrm{~mm})$, and semiarid $(250 \mathrm{~mm} \leq \mathrm{P}<500 \mathrm{~mm}$ ) regions (Thomas 2011).

In addition to the PREC/L, we used the corresponding surface air temperature (SAT) dataset of CPC in this study, which is labelled as the GHCN_CAMS Gridded $2 \mathrm{~m}$ temperature (Fan and Van den Dool 2008). This dataset has the same temporal coverage and spatial resolution as the PREC/L. To justify the uncertainty of the dataset, it was compared with several observation-based SAT datasets, such as the Parameter-Elevation Regressions on Independent Slopes Model (PRISM) dataset, ${ }^{1}$ the National Climate Data Center (NCDC) Climate Division Data, and the Climate Research Unit (CRU) dataset. The preliminary results show that the quality of GHCN_CAMS land SAT analysis is reasonably high and that it can capture most of the common temporal-spatial features in observed climatology as well as the anomaly fields over both the regional and global domains (Fan and Van den Dool 2008).

\subsection{Estimation of potential evapotranspiration (PET)}

The methods commonly used to estimate PET in climate studies are typically classified into three types: temperature-based methods (Thornthwaite 1948; Hamon 1963; Hargreaves and Samani 1985), radiation-based methods (Makkink 1957; Priestley and Taylor 1972; Turc 1961) and combination methods (Penman 1948; Monteith 1981).

Because air temperature is correlated with net radiation and humidity, temperature-based PET methods appear to perform relatively well in climatological applications (Shaw and Riha 2011). However, recent studies indicate that simple temperature-based PET estimates are not appropriate for determining trends such as long-term evaporative demands and drought projections (Sheffield et al. 2012; McAfee 2013; Greve et al. 2014) because temperature is not always the primary factor controlling PET (Donohue et al. 2010; Shaw and Riha 2011; Hobbins et al. 2012). In fact, PET is not only a function of air temperature but also of radiative and aerodynamic controls (Penman 1948).

\footnotetext{
${ }^{1}$ PRISM group, Oregon State University, see http://www.prismclimate.org.
} 
Regarding radiation-based PET methods, the Priestley and Taylor (1972) method is a simplification of the PenmanMonteith method. The former only retains the radiation term, and it explicitly ignores the impact of the aerodynamic control term, which is the effect of the water vapour pressure deficit (VPD), wind speed and canopy resistance (Wang and Dickinson 2012). It has been noted that the failure to explicitly account for changes in available energy, air humidity, and wind speed can cause some drought indices to identify an artificial trend towards more droughts under a warming climate (Sheffield et al. 2012).

The Penman-Monteith algorithm is derived from physical principles, and it is superior to empirically based formulations, which usually only consider the effect of temperature and radiation. The Penman-Monteith algorithm used in this study considers many meteorological parameters related to the evapotranspiration process, such as net radiation, relative humidity, wind speed and temperature data, as well as information on vegetation characteristics (Allen et al. 1998).

$\mathrm{PET}=\frac{0.408 \Delta\left(R_{n}-G\right)+\gamma \frac{900}{T_{a}+273} u_{2}\left(e_{s}-e_{a}\right)}{\Delta+\gamma\left(1+0.34 u_{2}\right)}$

where $R_{n}$ is the net radiation at the crop surface $\left(\mathrm{MJ} \mathrm{m}^{-2}\right.$ $\left.\mathrm{d}^{-1}\right), G$ is the soil heat flux density at the soil surface (MJ m $\left.{ }^{-2} \mathrm{~d}^{-1}\right), T_{a}$ is the mean daily air temperature at a $2-\mathrm{m}$ height $\left({ }^{\circ} \mathrm{C}\right), u_{2}$ is the wind speed at a $2-\mathrm{m}$ height $(\mathrm{m} / \mathrm{s}), e_{\mathrm{s}}$ is the saturation vapor pressure at a $2-\mathrm{m}$ height $(\mathrm{kPa}), e_{a}$ is the actual vapor pressure at a $2-\mathrm{m}$ height $(\mathrm{kPa})$, $\Delta$ is the slope of the vapor pressure-temperature curve $\left(\mathrm{kPa} /{ }^{\circ} \mathrm{C}\right)$, and $\gamma$ is the psychometric constant $\left(\mathrm{kPa} /{ }^{\circ} \mathrm{C}\right)$. The employed data of net surface radiation (include shortwave and longwave net radiaton), specific humidity, wind speed, and soil heat flux density are from the data product of Global Land Data Assimilation Systems (GLDAS) at a $0.5^{\circ}$ resolution; the data begin in1948 (Rodell et al. 2004). The solar radiation data are corrected for 19832000 based on two global radiation products (Sheffield et al. 2006). Specific humidity and wind speed data are adjusted according to the observationally based climatological methods developed by the CRU at the University of East Anglia (Mitchell and Jones 2005). The regionally averaged wind speed trends from GLDAS are -0.0009 and $-0.0013 \mathrm{~m} \mathrm{~s}^{-1} \mathrm{a}^{-1}$ in global land surface and Northern Hemisphere (see Fig. S1 \& Fig. S2 in Supplementary) respectively, which are consistent with the declining trend in observed near-surface wind speed $\left(-0.014 \mathrm{~m} \mathrm{~s}^{-1} \mathrm{a}^{-1}\right)$ as indicated by McVicar et al. (2012). However, the magnitude of trend in GLDAS is much less than that of the observations over global land, so we should note that using the GLDAS wind speed dataset may lead to biases toward increasing PET and drying climate in some areas because GLDAS gets its wind speed and humidity from NCEP/
National Center for Atmospheric Research (NCAR) reanalysis, not from surface observations.

\subsection{Aridity index (AI)}

The aridity index (AI) represented the degree of climatic dryness is defined as the ratio of annual precipitation $(\mathrm{P})$ to annual potential evapotranspiration (PET). For the purposes of the AI, drylands are defined as regions with AI of less than 0.65 and are further classified into hyper-arid $(\mathrm{AI}<0.05)$, arid $(0.05 \leq \mathrm{AI}<0.2)$, semi-arid $(0.2 \leq \mathrm{AI}<0.5)$, and dry sub-humid $(0.5 \leq \mathrm{AI}<0.65)$ subtypes (Middleton and Thomas 1997). The hyper-arid regions are the driest, and followed by arid, semi-arid, and dry sub-humid regions in all four types of drylands. The $\mathrm{AI}$ is provided by Feng and $\mathrm{Fu}$ (2013) and calculated from 1948 to 2008 , and the spatial resolution of the data is $0.5^{\circ}$ by $0.5^{\circ}$.

In addition, Feng and Fu (2013) verified the uncertainty of different datasets when calculating PET and AI. Two temperature and precipitation datasets were used: the CPC PREC/L and University of Delaware (UDel) (Legates and Willmott 1990a, b) datasets. The solar radiation, specific humidity and wind speed used to calculate the PET were also selected from two datasets: the GLDAS and the Twentieth Century Reanalysis (20CR) datasets (Compo et al. 2011). Therefore, four combinations (i.e., CPC and GLDAS, CPC and 20CR, UDel and GLADS, UDel and 20CR) were obtained and compared. The results showed a good agreement in the global averaged temporal variations. However, we note that the trends may be slight different in specific regions by using individual precipitation datasets, especially in Central Asia (see Fig. S3-S6 in Supplementary). As indicated by Schiemann et al. (2008), the precipitation pattern is most realistically represented using UDel in central Asia by comparing a wide range of observational precipitation data sets, and the large biases of the observed precipitation may be leaded by the foothills of the large mountain systems such as the central Tien Shan and the eastern Pamirs regions of very little precipitations. For similar precipitation trends in the semi-arid regions from UDel and PREC/L in central Asia, we note that the data set of $\mathrm{PREC} / \mathrm{L}$ precipitation seems also reasonable to present the changes of precipitation trend in central Asia.

\subsection{Köppen-Geiger climate classification}

Since the Köppen climate classification was first proposed by Köppen (1884), various classifications based on Köppen's original method have been developed, such as Thornthwaite-type method (Thornthwaite 1948; Feddema 2005), Köppen-Trewartha (Trewartha and Horn 1980), Köppen-Geiger method (Köppen 1936; Geiger 1954). 
Generally, the Köppen-Trewartha is a simplified method used in many studies, which is only developed by using temperature and precipitation, and the Thornthwaite-type method is infrequently used because it is too complex (Thornthwaite 1948; Feddema 2005). Comparing with the above methods, the Köppen-Geiger method is based on the vegetation types of a region, together with temperature and precipitation, and it is the most common climate classification in use. As a result, we choose Köppen-Geiger classification in this paper. Recently, updates to the Köppen-Geiger climate classification were published in several studies based on observed temperature and precipitation (Kottek et al. 2006; Peel et al. 2007). In this work, we adopt the Köppen-Geiger climate classification map for the period of $1951-2000$ with $0.5^{\circ}$ resolution; this map was published by Kottek et al. (2006). Both the map and the underlying digital data are available online at http:// koeppen-geiger.vu-wien.ac.at/present.htm. These data produce a total of 31 climate classes described by three letters. The first letter describes the main classes, namely, equatorial climates (A), arid climates (B), warm temperate climates (C), snow climates (D) and polar climates (E). In this work, we describe only the four arid classes of type B, i.e., hot desert climate (BWh), cool desert climate (BWk), hot steppe climate (BSh), and cool steppe climate (BSk). The second letter accounts for precipitation, where "W" represents desert and "S" represents steppe. The third letter denotes the temperature, where " $h$ " and " $k$ " are warm and cool, respectively.

(a)

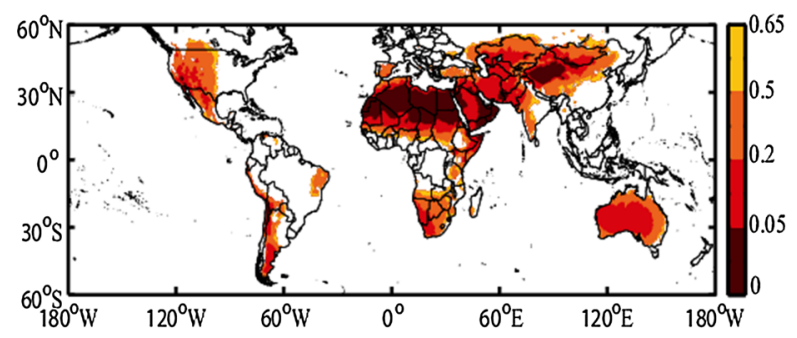

(c)

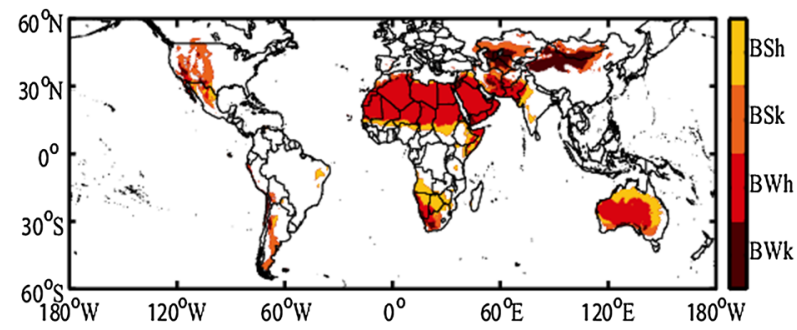

\subsection{Circulation data}

The East Asia summer monsoon (EASM) index, which is archived at http://ljp.gcess.cn/dct/page/65544, is used here. The EASM index is defined using the area-averaged, JJAaveraged, dynamically-normalized winds at $850 \mathrm{hPa}$ within the East Asian monsoon domain $\left(10^{\circ}-40^{\circ} \mathrm{N}, 110^{\circ}-140^{\circ} \mathrm{E}\right)$. For details of this normalization, please see $\mathrm{Li}$ and Zeng (2002). In addition, the NCEP/NCAR reanalyses including the geopotential heights (HGT) and winds at $850 \mathrm{hPa}$ are also used here (Kalnay et al. 1996).

\section{Comparison of dryland definitions}

The spatial distributions of drylands (as identified by AI or annual precipitation from 1961 to 1990 and the KöppenGeiger climate classification for 1951-2000) are shown in Fig. 1a-c. Although there are no fixed or precise limits for the biomes, the major dryland biomes include savanna, grassland, and desert (Safriel and Adeel 2005). Figure 1d shows the major dryland surface vegetation types from MODIS. As shown in Fig. 1a, global drylands defined by $\mathrm{AI}$ is primarily distributed in the middle and low latitudes and closely match the map from UNEP (Middleton and Thomas 1997). Major hyper-arid areas occur over the central and northern Sahara Desert, the Rub al Khali Desert in the eastern Arabian Peninsula, the Iran/Afghanistan/Pakistan border area, the Taklimakan Desert in northwestern (b)

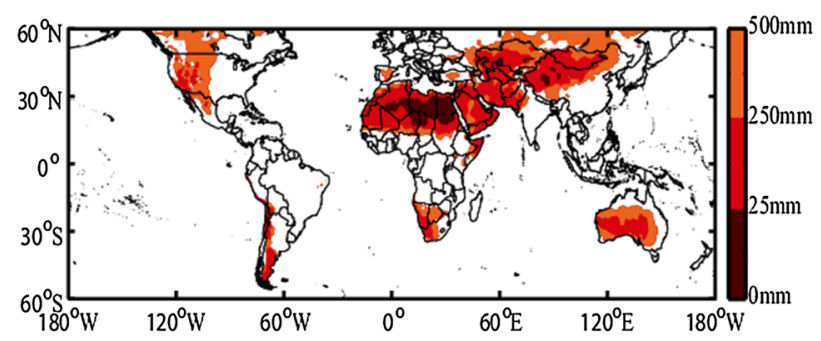

(d)

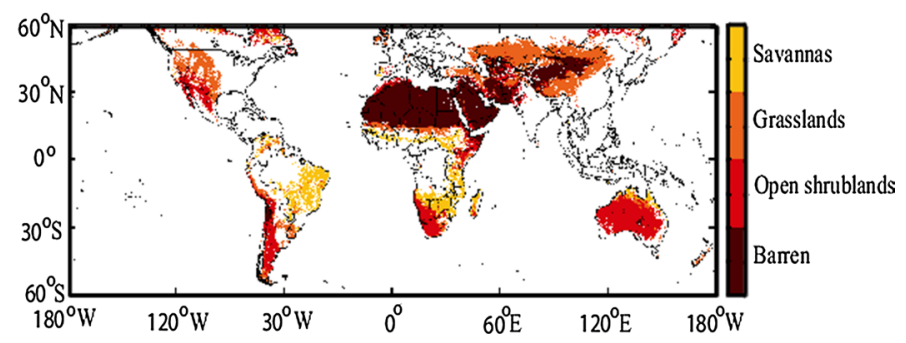

resolution imaging spectroradiometer (MODIS) (ISLSCP II MODIS (Collection 4) IGBP Land Cover), available online at http://daac.ornl. gov/cgi-bin/dsviewer.pl?ds_id=968 
China, the Gobi Desert in Mongolia/China border area and the Atacama Desert area (Fig. 1a), where the MODIS land cover types are barren (Fig. 1d). Generally, arid areas are located over the southern Sahara Desert, southern Africa, western Arabia Peninsula, Central Asia, areas of Mongolia and northern China, and much of Australia (Fig. 1a), where the land cover types are barren or sparsely vegetated, i.e., shrubland and grassland (Fig. 1d). Semi-arid and dry subhumid regions are located in the western United States, the west coast of South America, Central and East Asia and a large portion of Australia outside of the central desert regions, where the land cover type is primarily grassland (Fig. 1d).

Compared with Fig. 1a, the dryland area defined by annual precipitation (Fig. 1b) is significantly smaller than that defined by AI everywhere except for the latitudes around $50^{\circ}-60^{\circ} \mathrm{N}$. The dryland area defined by precipitation is larger in Asia and North America at approximately $60^{\circ} \mathrm{N}$, such as in Siberia, while the AI classifies these areas as humid, due to the low PET. In Fig. 1c, the Köppen-Geiger BWh subtype is located in the subtropical latitudes between $30^{\circ} \mathrm{S}$ and $30^{\circ} \mathrm{N}$. Such areas include the entire Sahara Desert, the Arabian Peninsula, large regions of Iran, southern Pakistan and Afghanistan, southern Africa, and much of Australia. The BWk areas are mainly located in East and Central Asia, as well as small areas in the Great Basin Desert of the western United States, northern Africa and southern Australia. The BSh regions tend to be located in the tropics and subtropics, which are most commonly found along the fringes of subtropical deserts. This type of area is primarily located in regions such as the Sahel in northern Africa, southern Africa, small portions of India and Mexico, and a large portion of Australia outside of the central desert regions. This type of region also can be found on the poleward side of the northern Africa deserts, which typically feature a Mediterranean climate. The BSk subtype tends to be located in temperate zones, and the majority of these areas are located in East Asia, Central Asia and North America in the Northern Hemisphere and sections of South America and interior southern Australia in the Southern Hemisphere.

Of the three definitions of drylands, the AI definition is most reasonable and reliable, and the dryland coverage agrees well with the surface vegetation types. Obviously, precipitation alone is insufficient for defining climatic boundaries (Safriel and Adeel 2005). In Australia, for example, the generally accepted limit for an arid zone is $250 \mathrm{~mm}$, but particular areas of the tropical northwest are clearly arid even though the mean annual rainfall exceeds $500 \mathrm{~mm}$ (Mabbutt 1979). In addition, the annual precipitation in Siberia is less than $500 \mathrm{~mm}$, but the major land cover type is forest, and the climate is humid. As investigated in previous studies, the Köppen-Geiger climate classification may mistakenly classify regions with distinctively different weather patterns and vegetation as belonging to the same climate type (Trewartha and Horn 1980). For example, western Washington and Oregon in the northwest US are classified as the same climate type as southern California (in the southwest US), although the two regions have strikingly different weather and vegetation types (Feng et al. 2014). Furthermore, particular drylands may be classified as other climate types, i.e., Mediterranean semi-arid regions, which are classified as Csb or Csa by the Köppen-Geiger climate classification, where the "s" indicates "summer dry" and "b" and "a" indicate "warm summer" and "hot summer", respectively. Thus, the arid climate (type B) defined by the Köppen-Geiger climate classification does not represent the total drylands, and it is significantly smaller than the global drylands because several climate subtypes are classified in each major climate type based on the seasonal variations in temperature and precipitation. Compared with Fig. 1a, the drylands defined by the Köppen-Geiger climate classification are significantly smaller in most areas, i.e., East Asia, Central Asia, and North America. As indicated by Kottek et al. (2006), a total of $29.1 \%$ of the global land area is covered by Köppen-Geiger arid climates, but the areal coverage of the total drylands according to the AI definition is $6.1 \times 10^{7} \mathrm{~km}^{2}$, or $41 \%$ account for the global land (Safriel and Adeel 2005). Thus, the drylands in the following sections are based on the definition of AI.

\section{Expansion of semi-arid regions}

The dryland subtypes of hyper-arid, arid, semi-arid and dry sub-humid cover $1.1 \times 10^{7} \mathrm{~km}^{2}, 1.9 \times 10^{7} \mathrm{~km}^{2}, 2.3 \times 10^{7}$ $\mathrm{km}^{2}$, and $0.9 \times 10^{7} \mathrm{~km}^{2}$, accounting for $7,13,15$, and $6 \%$ of the land surface, respectively. For all of these subtypes of global drylands, the semi-arid region is the largest, and it accounts for more than one-third of the total dryland area.

Figure 2 shows the temporal variations in the areal coverage of drylands and its subtypes from 1948 to 2008. The global drylands have greatly expanded because the dryland area in the more recent 15 years (1990-2004) is $2.6 \times 10^{6}$ $\mathrm{km}^{2}$ (or $4 \%$ ) larger than that during 1948-1962 (Fig. 2a). Feng and Fu (2013) also obtained similar results by analyzing the observations for 1948-2008. The expansions of the dryland subtypes are $0.6 \times 10^{6},-0.1 \times 10^{6}, 1.6 \times 10^{6}$, and $0.5 \times 10^{6} \mathrm{~km}^{2}$ for the hyper-arid, arid, semi-arid and dry sub-humid categories, respectively (Fig. 2b-e). The largest dryland expansion has occurred in semi-arid regions, where the area has expanded since the early 1960s, accounting for more than half of the total dryland expansion (Fig. 2c). The area of dry sub-humid regions experienced few fluctuations prior to the 1980s, decreased in the early 1980s, 
Fig. 2 Temporal variations in the area (units: $10^{6} \mathrm{~km}^{2}$ ) for a total drylands, b dry sub-humid regions, c semi-arid regions, $\mathbf{d}$ arid regions, and $\mathbf{e}$ hyperarid regions for the period of 1948-2008. The 15-year running mean (thick blue curves) is applied to emphasize climate change

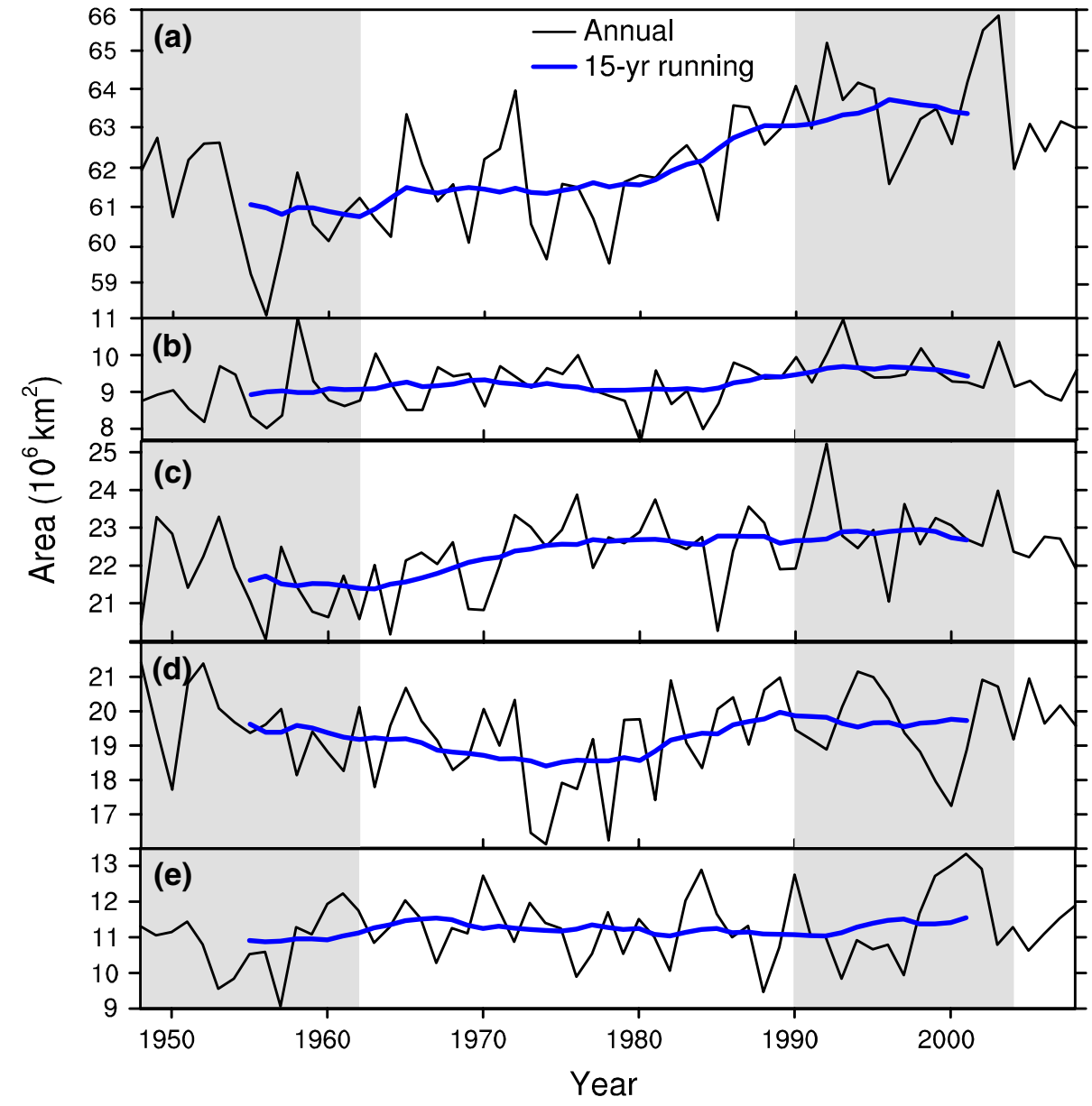

and significantly expanded after the late 1980s. The areal changes in arid regions show strong decadal variations, with large areas before the 1970s, reduced areas in the 1970s, and resumed expansion in the early 1980s; the area for the most recent 15 years is comparable with that present before the 1970s. The arid regions had the smallest areas during the 1970s as a result of large positive precipitation anomalies in the Southern Hemisphere, which led to a transition from arid to semi-arid regions (Feng and $\mathrm{Fu} 2013$ ).

The AI of a semi-arid region is within the range of $0.2-0.5$, according to the definition. Transitions from semi-arid regions to other dryland subtypes will occur if the AI falls outside the range of 0.2-0.5. To understand the changes in semi-arid regions during the last 61 years, two periods are chosen: the first 15 years (from 1948 to 1962) and the most recent 15 years (from 1990 to 2004) of the monitoring period. Table 1 shows all of the transitions in the semi-arid regions, which include arid to semiarid, sub-humid/humid to semi-arid, semi-arid to arid, and semi-arid to sub-humid/humid regions. The newly formed semi-arid regions that transited from other subtypes are $4.1 \times 10^{6} \mathrm{~km}^{2}$ and they are formed by two transitions from arid to semi-arid regions $\left(1.1 \times 10^{6} \mathrm{~km}^{2}\right)$ and sub-humid/
Table 1 The area transitions $\left(10^{6} \mathrm{~km}^{2}\right)$ between semi-arid regions and other classes for 1990-2004 relative to 1948-1962

\begin{tabular}{lll}
\hline Semi-arid to arid & Sub-humid to semi-arid & Humid to semi-arid \\
1.6 & 2.84 & 0.11 \\
Arid to semi-arid & Semi-arid to sub-humid & Semi-arid to humid \\
1.1 & 0.87 & 0.01 \\
\hline
\end{tabular}

humid to semi-arid regions $\left(3.0 \times 10^{6} \mathrm{~km}^{2}\right)$. The amount of the decrease from semi-arid regions to other subtypes is $2.5 \times 10^{6} \mathrm{~km}^{2}$, which also includes two transitions from semi-arid to arid regions $\left(1.6 \times 10^{6} \mathrm{~km}^{2}\right)$ and semi-arid to sub-humid/humid regions $\left(0.9 \times 10^{6} \mathrm{~km}^{2}\right)$. Therefore, the net change in the semi-arid region is $1.6 \times 10^{6} \mathrm{~km}^{2}$ by subtracting the reduced areas from the newly formed areas. Comparing the two types of shifts, the semi-arid area that transited from sub-humid/humid regions is nearly 3 times larger than that from arid regions. This result indicates that the newly formed semi-arid regions primarily transited from sub-humid and humid regions, which account for $73 \%$ of the newly formed semi-arid regions. Comparing the transitions between semi-arid (sub-humid/humid) and 


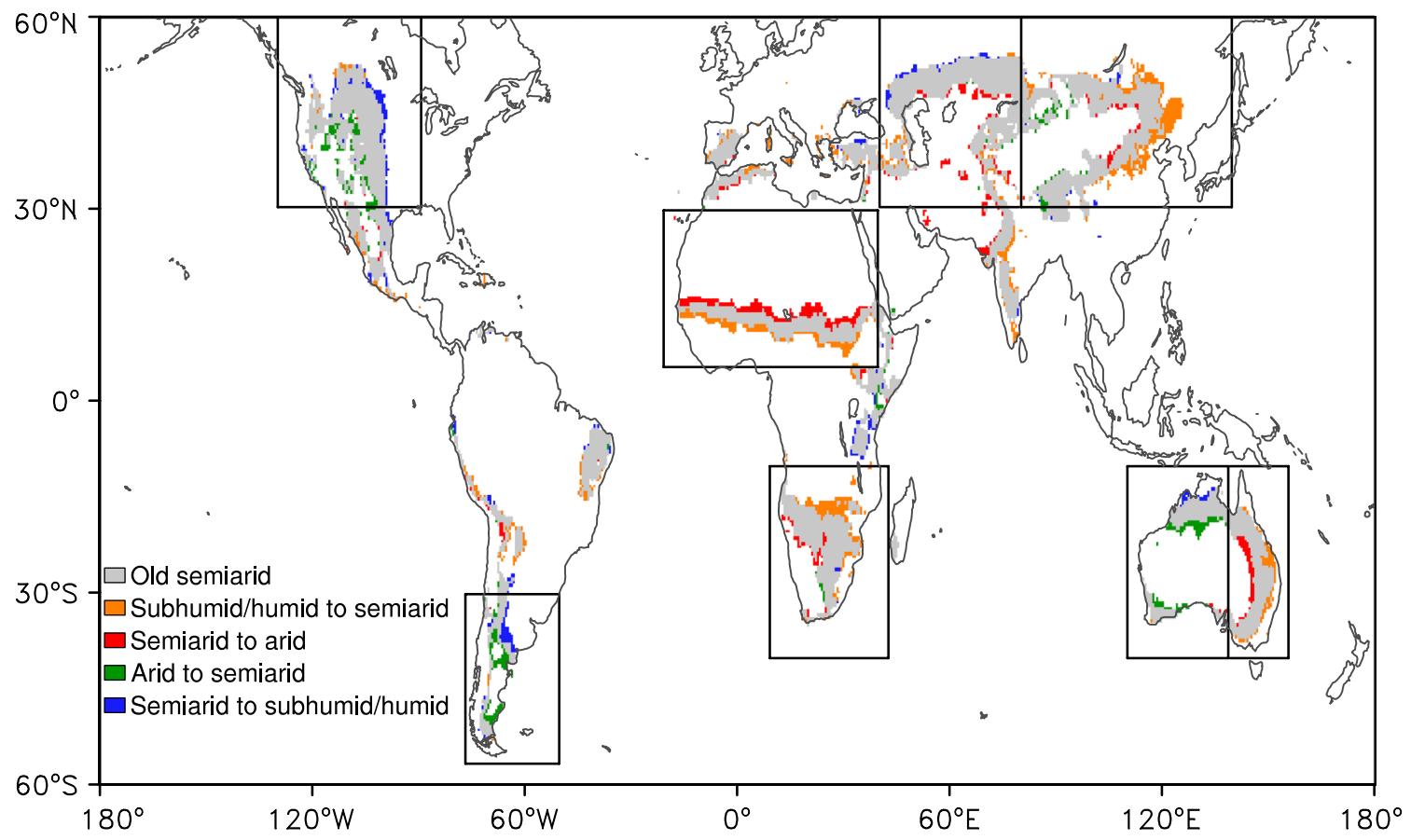

Fig. 3 Global distribution of semi-arid regions and their transitions to other climate classifications, including old semi-arid regions (grey), sub-humid/humid to semi-arid regions (orange), semi-arid to

arid (semi-arid) regions, the area transiting from semi-arid (sub-humid/humid) to arid (semi-arid) is much larger than that transiting from arid (semi-arid) to semi-arid (subhumid/humid); therefore, more semi-arid (sub-humid/ humid) regions become drier.

Figure 3 demonstrates the global distribution of semiarid regions and their transitions to other subtypes. As shown in Fig. 3, the transition from sub-humid/humid (semi-arid) to semi-arid (arid) primarily occurs in East Asia, east Australia, and northern and southern Africa. The transition from semi-arid (arid) to sub-humid/humid (semi-arid) occurs in central/west Australia, the central US, and southern South America. The results indicate that the transitions to drier types primarily occurred in the Eastern Hemisphere, except for in central/west Australia, whereas the shifts to wetter types occurred in the mid-latitudes in North and South America. Notably, two temperate semiarid regions in North America and East Asia show different changes, in which more arid and semi-arid regions became wetter in North America but semi-arid and dry subhumid regions became drier in East Asia. To investigate the regional climate changes in semi-arid regions globally, eight semi-arid regions are selected, i.e., East Asia, Central Asia, northern Africa, North America, South America, southern Africa, central/west Australia, and east Australia. The latitude/longitude information is listed in Table 2 and labeled in Fig. 3. arid regions (dark red), arid to semi-arid regions (dark green), and semi-arid to sub-humid/humid regions (blue) for 1990-2004 relative to $1948-1962$

Table 2 Latitude/longitude information for eight regions

\begin{tabular}{llll}
\hline & Region & Longitude (E) & Latitude (N) \\
\hline 1 & East Asia & $80^{\circ}$ to $140^{\circ}$ & $30^{\circ}$ to $60^{\circ}$ \\
2 & Central Asia & $40^{\circ}$ to $80^{\circ}$ & $30^{\circ}$ to $60^{\circ}$ \\
3 & Northern Africa & $-20^{\circ}$ to $40^{\circ}$ & $5^{\circ}$ to $30^{\circ}$ \\
4 & North America & $-130^{\circ}$ to $-89^{\circ}$ & $30^{\circ}$ to $60^{\circ}$ \\
5 & South America & $-77^{\circ}$ to $-50^{\circ}$ & $-60^{\circ}$ to $-30^{\circ}$ \\
6 & Southern Africa & $9^{\circ}$ to $43^{\circ}$ & $-40^{\circ}$ to $-10^{\circ}$ \\
7 & Central/West Australia & $110^{\circ}$ to $139^{\circ}$ & $-40^{\circ}$ to $-10^{\circ}$ \\
8 & East Australia & $139^{\circ}$ to $156^{\circ}$ & $-40^{\circ}$ to $-10^{\circ}$ \\
\hline
\end{tabular}

The shifts from sub-humid/humid to semi-arid, semiarid to arid, semi-arid to sub-humid/humid, and arid to semi-arid for eight typical semi-arid regions are shown in Fig. 4. The results show that, except for Central Asia and northern Africa, 6 semi-arid areas in the most recent 15 years (1990-2004) are larger than those during 19481962. The largest semi-arid expansion occurred in East Asia, which accounts for nearly $50 \%$ of the global semiarid expansion. In comparing the four semi-arid regions in the Northern Hemisphere, except for North America, the area that shifted to a drier class is much larger than the area that shifted to a wetter class, particularly in East Asia and northern Africa (Fig. 4a, b). For example, the area that shifted to drier classes is four times larger than the area that 
Fig. 4 The transitions from sub-humid/humid to semi-arid, semi-arid to arid, semi-arid to sub-humid/humid, and arid to semi-arid regions over the eight semi-arid regions of

a East Asia, Central Asia, northern Africa (in the Eastern Hemisphere); b North America (in the Northern Hemisphere); c southern Africa, central/west Australia, and east Australia (in the Eastern Hemisphere); and d South America (in the Southern Hemisphere)
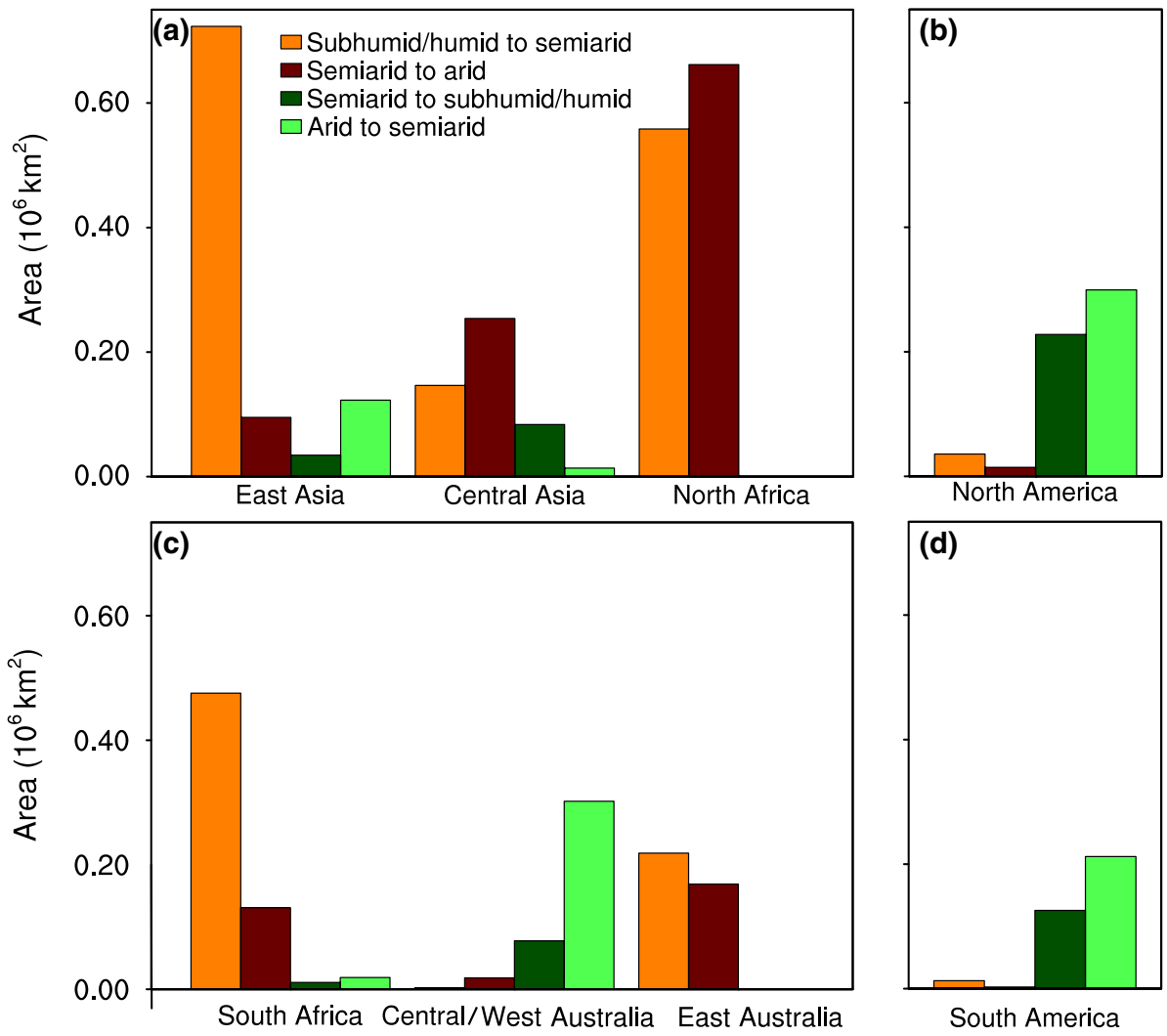

Table 3 The areal changes $\left(10^{6} \mathrm{~km}^{2}\right)$ in semi-arid regions over the American continents and the continents in the Eastern hemisphere

\begin{tabular}{lll}
\hline Change & $\begin{array}{l}\text { Eastern } \\
\text { hemisphere }\end{array}$ & America \\
\hline Sub-humid/humid to semi-arid & 2.6 & 0.4 \\
Semi-arid to arid & 1.5 & 0.1 \\
Semi-arid to sub-humid/humid & 0.4 & 0.5 \\
Arid to semi-arid & 0.5 & 0.6 \\
\hline
\end{tabular}

shifted to wetter classes in East Asia. However, in North America, the area that shifted to wetter types is nearly ten times larger than the area that shifted to drier categories. In the Southern Hemisphere, the climate primarily shifted to drier categories in southern Africa and east Australia but shifted to wetter categories over central/west Australia and South America (Fig. 4c, d). In all eight semi-arid regions considered, two of the three regions that shifted to wetter types are within the American continents.

The area changes in the semi-arid regions between the American continents and the Eastern Hemisphere are shown in Table 3. The semi-arid areas in the more recent 15 years $(1990-2004)$ are $0.4 \times 10^{6} \mathrm{~km}^{2}$ and $1.2 \times 10^{6}$ $\mathrm{km}^{2}$ larger than those during 1948-1962 within the American continents and in the Eastern Hemisphere, respectively. Although expansions of semi-arid regions occur in both areas, the shifting patterns of the expansion are different. The newly formed semi-arid regions shift from arid regions, in which the climate becomes wetter within the American continents. Conversely, in the continents of the Eastern Hemisphere, the expansion of semi-arid regions replaces the sub-humid/humid regions in which the climate becomes drier. For example, the transition from subhumid/humid to semi-arid classes occurs over $2.6 \times 10^{6}$ $\mathrm{km}^{2}$ of the continental Eastern Hemisphere; this area is five times larger than the area transited from arid to semiarid $\left(0.5 \times 10^{6} \mathrm{~km}^{2}\right)$. Within the American continents, the areal change in the sub-humid/humid to semi-arid areas $\left(0.4 \times 10^{6} \mathrm{~km}^{2}\right)$ is less than the areal change from arid to semi-arid $\left(0.6 \times 10^{6} \mathrm{~km}^{2}\right)$. The results indicate that wetting of arid regions plays an important role in the expansion of semi-arid areas in the American continents versus the drying climate trend in the continents of the Eastern Hemisphere. The causes of the different behaviors between the American continents and the Eastern Hemisphere are addressed in Sect. 6.

\section{Semi-arid climate change}

Climate change associated with changes in precipitation and PET would lead to changes in AI and thus in the areal extent of drylands and its subtypes. The linear trends in 


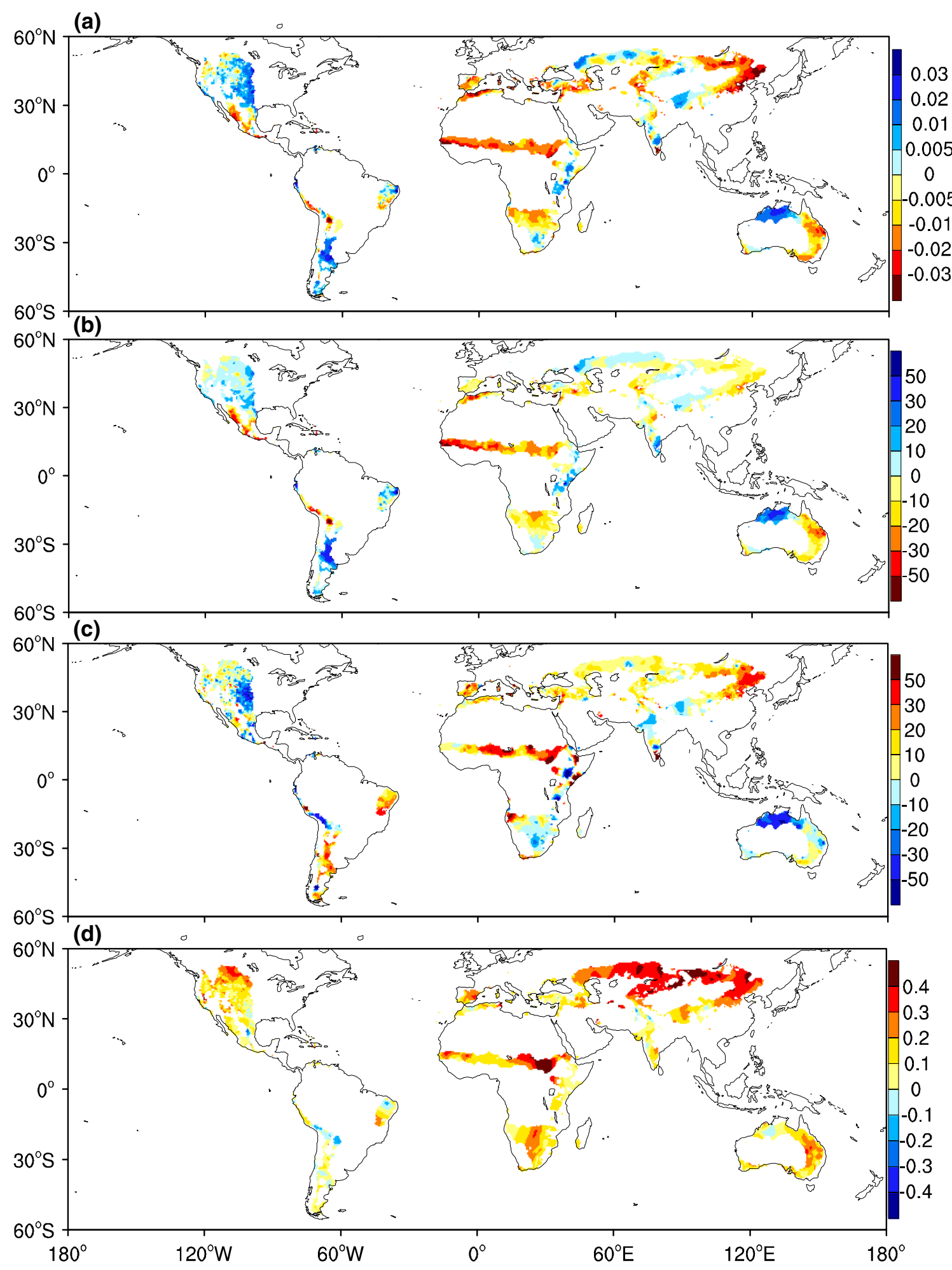

Fig. 5 The distributions of the linear trends in the AI, precipitation, PET, and SAT in semi-arid regions globally from 1948 to 2008. a P/PET trend (/decade), b P trend ( $\mathrm{mm} /$ decade), $\mathbf{c}$ PET trend (mm/decade), $\mathbf{d}$ temprature trend $\left({ }^{\circ} \mathrm{C} /\right.$ decade)

AI, precipitation, and PET in semi-arid regions from 1948 to 2008 are shown in Fig. 5. The AI decreases, suggesting drying trends during the last 61 years over East Asia, including northeastern China, northern Mongolia, east Australia, the Sahel in northern Africa, southern Africa, and Mediterranean regions, while wetter trends are apparent in 
East Asia

(a)

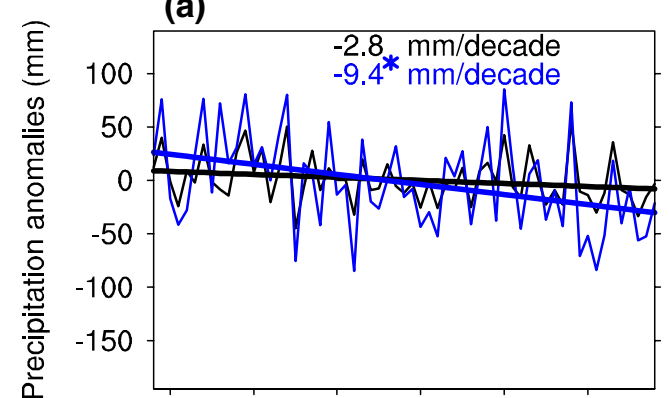

(b)

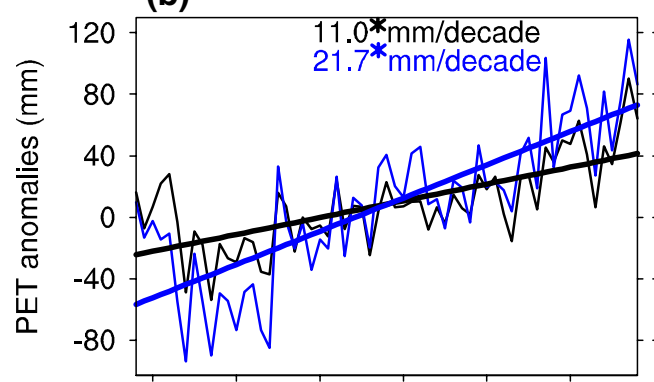

(c)

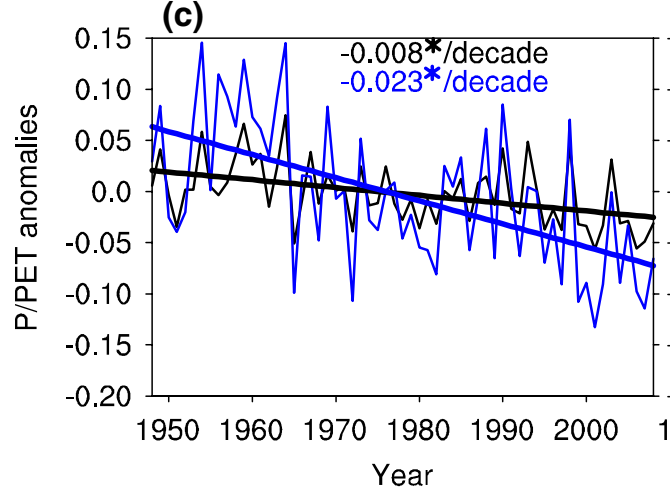

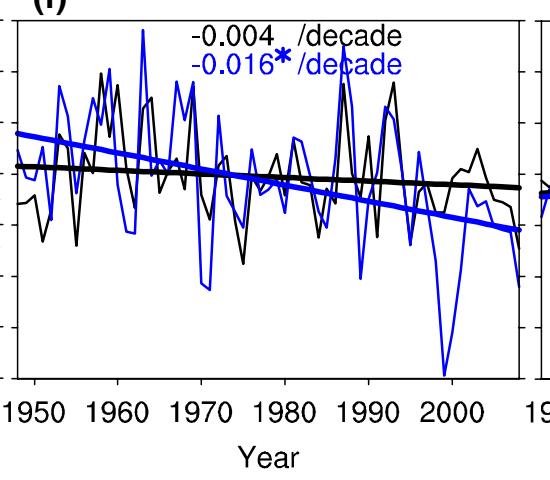

Central Asia

(d)

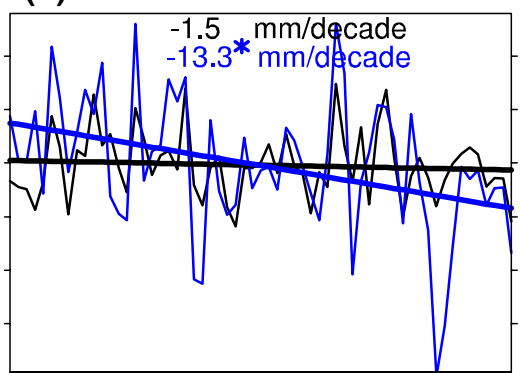

(e)

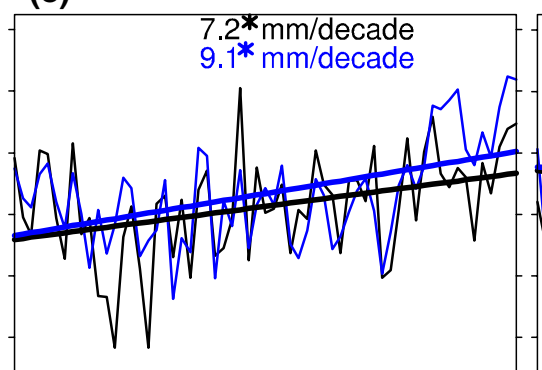

(f)
North America

(g)

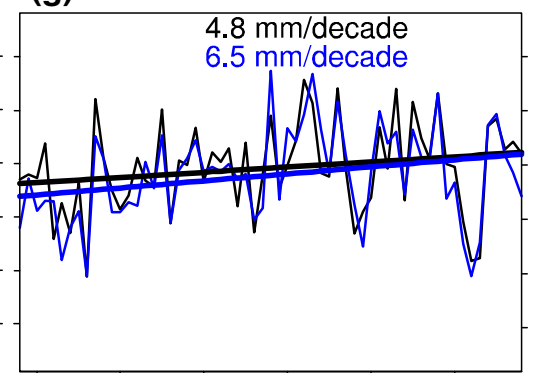

(h)

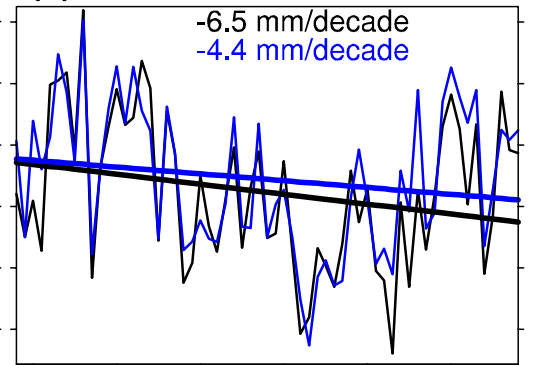

(i)

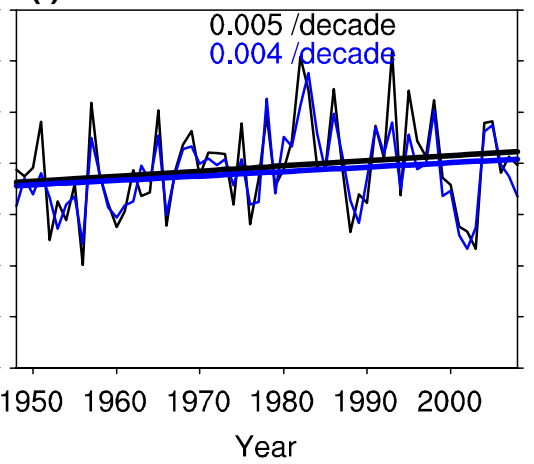

Fig. 6 The variations in the regionally averaged precipitation, PET, and $\mathrm{AI}$ in the semi-arid regions over East Asia (left column), Central Asia (middle column), and North America (right column) from 1948 to 2008. The blue curve indicates the newly formed semi-arid

central/west Australia, South America, North America, and other small areas, such as northern Central Asia and western China (Fig. 5a). Precipitation decreases in the Sahel, southern Africa, east Australia, and East Asia but increases in central/west Australia and within the American continents (Fig. 5b). The patterns of precipitation are consistent with those for AI, with only particular regional differences. This result suggests that precipitation is a key factor that affects AI. The PET decreases over the American continent, but PET increases over other Northern Hemisphere continents. However, this pattern is reversed in the Southern Hemisphere, and the PET increases in South America but decreases in southern Africa and northern Australia (Fig. 5c). During the same period, the surface air temperature (SAT) warms in most of the semi-arid regions; this regions, and the black curve denotes the old semi-arid regions. The thick blue (black) line illustrates the linear trend for the curve, and a asterisk indicates a trend that exceeds the $99 \%$ confidence level. a, d, g Annual precipitation. b, e, h Annual PET. c, f, i Annual P/PET

trend is particularly pronounced in the eastern Sahel and higher latitudes over the Northern Hemisphere, i.e., East and Central Asia (Fig. 5d). The different trends between the PET and temperature in particular regions, e.g., North America and southern Africa, imply that temperature is not always the primary factor controlling PET (Donohue et al. 2010; Shaw and Riha 2011; Hobbins et al. 2012), which is also influenced by other factors, such as, winds, net radiation, and humidity.

Figure 6 shows the variations in the regionally averaged precipitation, $\mathrm{PET}$, and $\mathrm{AI}$ in three mid-latitude semi-arid regions over East Asia, Central Asia, and North America in the Northern Hemisphere. Considering that the newly formed semi-arid regions transited from other climate types, they are different from the semi-arid regions of 
the same domain already in place; thus, each of the semiarid regions is divided into old and newly formed semiarid regions. In East Asia, precipitation decreases in both areas, but the decrease in the precipitation is $57 \mathrm{~mm}$ in the newly formed semi-arid regions; this value is 3 times higher than that in the old semi-arid regions (Fig. 6a). The PET increases by $132 \mathrm{~mm}$ in the newly formed semi-arid regions; this value is two times higher than that in the old semi-arid regions (Fig. 6b). The decrease in precipitation and increase in PET lead to a significant decrease in AI, which indicates that two types of semi-arid regions became drier over the past 61 years, particularly in the newly formed semi-arid regions (Fig. 6c). The PET increases significantly in both types of semi-arid regions in Central Asia (Fig. 6e). The rates of change in precipitation between the old and newly formed semi-arid regions are remarkably different (Fig. 6d). The regionally averaged precipitation shows a sharp decrease of $81 \mathrm{~mm}$ in the newly formed semi-arid regions; this value is nearly 9 times higher than that in old semi-arid regions. Thus, the decrease in the AI in the newly formed semi-arid regions is 4 times larger than that in the old semi-arid regions (Fig. 6f). The time series of regionally averaged precipitation, PET, and AI are consistent between the old and newly formed semi-arid regions, without significant changes in North America (Fig. 6g-i). The PET shows strong decadal variations, with the largest value occurring during the 1950s, observed decreases in the mid-1960s, and minimum values in the mid-1980s before increasing again in the early 1990s. The upward trend in precipitation and downward trend in PET leads to an increasing trend in the AI in both the old and newly formed semi-arid regions; thus indicates the semi-arid regions became wetter over the past 61 years. The annual variability in the AI is completely consistent with that of precipitation, which indicates that the precipitation is a dominating factor in the wetting trend of North America. Although historical records reveal that droughts occurred in the late 1980s and at the beginning of the 21st century, the higher AI and precipitation in the most recent 20 years provide evidence that the current climate is indeed becoming wetter compared with the climate of the 1950s in North America.

Comparing these regions in Fig. 6, the regionally averaged precipitation, PET, and AI show consistent upward or downward trends between the newly formed and old semi-arid regions. Precipitation decreases in East Asia and Central Asia but increases in North America, and the PET shows an increasing trend in East Asia and Central Asia, in contrast to the decreasing trend in North America. As a result, the AI is consistent with precipitation, which reveals that the climate becomes drier in East Asia and Central Asia but becomes wetter in North America. Notably, the changes of precipitation, PET and AI in the newly formed semi-arid regions are much larger than those in the old semi-arid regions in the drying semi-arid regions over East Asia and Central Asia. In contrast, the variations in the precipitation, PET and AI show little difference between the newly formed and old semi-arid regions in the wetting region over North America.

Northern Africa is also an important semi-arid region, which has received more attention because of the scarcity of rainfall and the long periods of drought that occurred in 1970s and 1980s (Dai et al. 2004; Hulme et al. 2001). The PET increases in both the old and newly formed semi-arid regions, and it has remained at a stable level since the $1980 \mathrm{~s}$ (Fig. 7b). The precipitation and AI both decrease significantly in the old and newly formed semi-arid regions, and the time series indicates strong decadal variations (Fig. 7a, c). The maximum values occur in the early 1950s; then, the values decrease and remain steady with reduced precipitation and AI until the mid-1980s. These values have partially recovered since the driest period in the mid-1980s. This decadal variation in precipitation was also demonstrated in

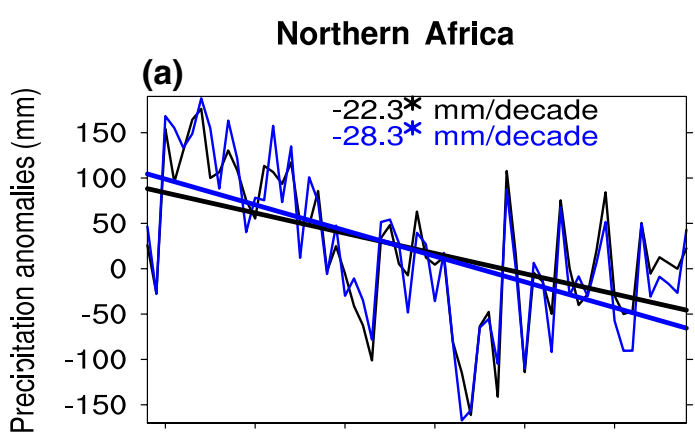

(b)

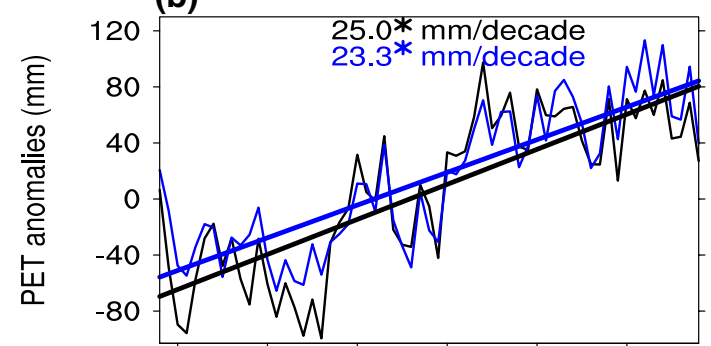

(c)

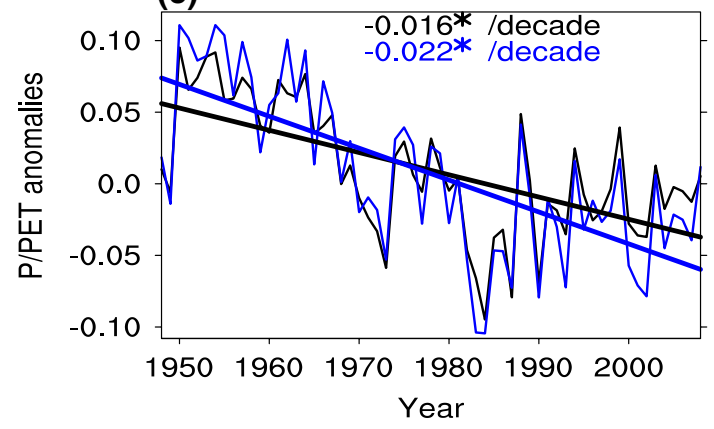

Fig. 7 Same as Fig. 6 but for northern Africa semi-arid regions. a Annual precipitation. b Annual PET. c AnnualP/PET 


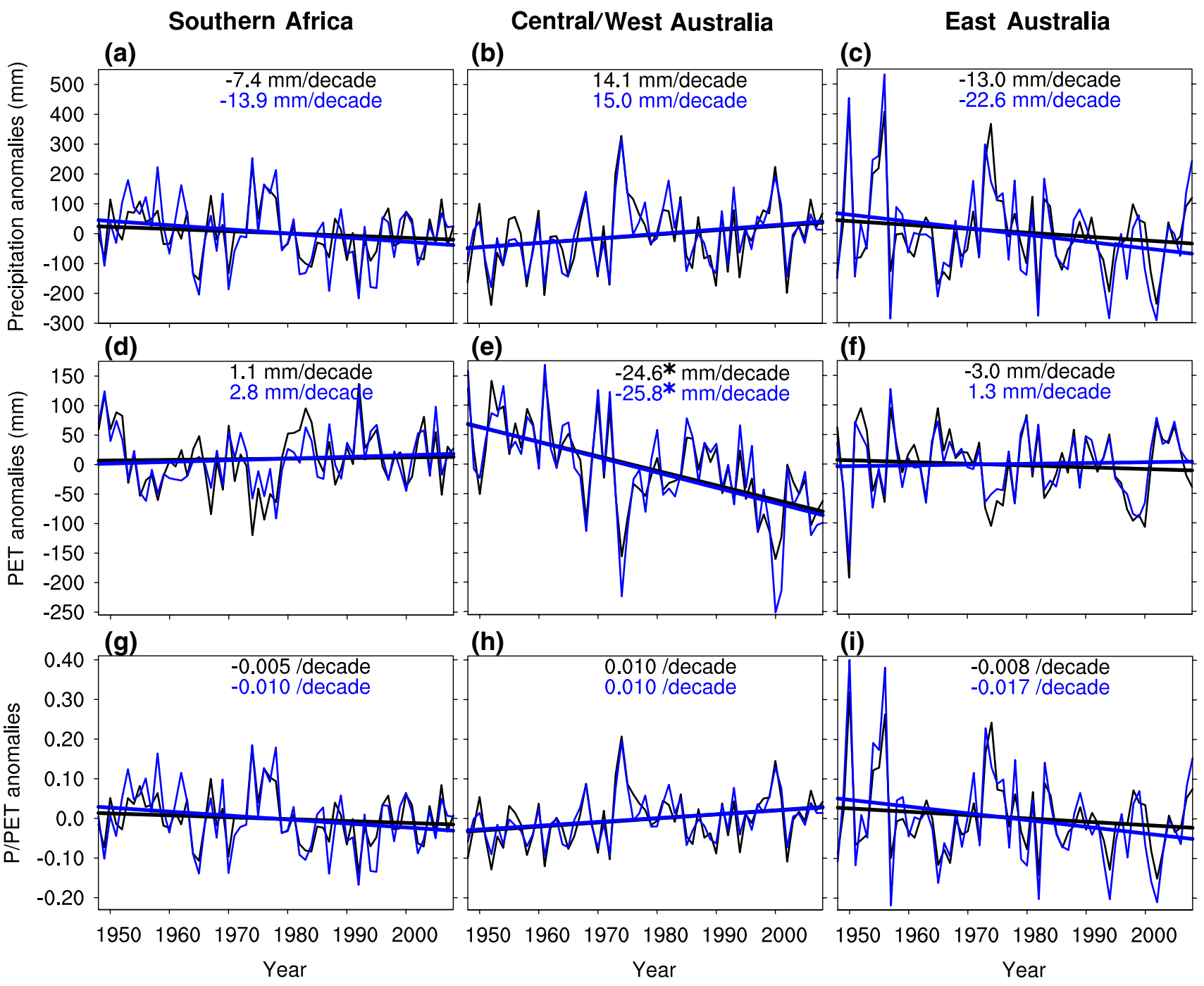

Fig. 8 Same as Fig. 6 but for southern Africa (left column), central/west Australia (middle column), and east Australia (right column) semi-arid regions. a-c Annual precipitation. d-f Annual PET. g-i Annual P/PET

previous studies (Dai et al. 2004; Hulme et al. 2001; Zeng et al. 1999).

For two severely drying semi-arid regions in the Northern Hemisphere over East Asia and northern Africa, the decrease in the precipitation in the old semi-arid regions over northern Africa is 8 times larger than the changes in East Asia; the rate of change in the decreasing PET also shows a rate twice as large as that in East Asia. As a result, the drying trend in the old semi-arid regions over northern Africa is more severe than that in East Asia. In contrast, during the same period, the precipitation decreases by $173 \mathrm{~mm}$ in the newly formed semi-arid regions over northern Africa, which is 3 times higher than that in East Asia $(57 \mathrm{~mm})$; only a slight difference is observed in the variability in the PET between East Asia and northern Africa. However, the AI changes are comparable in the newly formed semi-arid regions in East Asia and northern
Africa; thus, the drying trend in the newly formed semiarid regions in East Asia is more sensitive to the decrease in precipitation than the trend in northern Africa because the climatological PET of the newly formed semi-arid regions in northern Africa $(1785 \mathrm{~mm})$ is much larger than that in East Asia (902 mm).

Figure 8 shows the time series of the regionally averaged precipitation, PET, and AI in semi-arid regions over southern Africa, central/west Australia, and east Australia in the low latitudes of the Southern Hemisphere. The decreasing trends in the AI in southern Africa and east Australia reveal that the semi-arid regions became drier (Fig. 8g, i). Furthermore, the rates of change in the $\mathrm{AI}$ in the newly formed areas are much larger than the changes in the old semi-arid regions. In central/west Australia, the annual variations and linear trends in the regionally averaged precipitation, PET, and $\mathrm{AI}$ are all consistent between the old and new semi-arid 
(a)

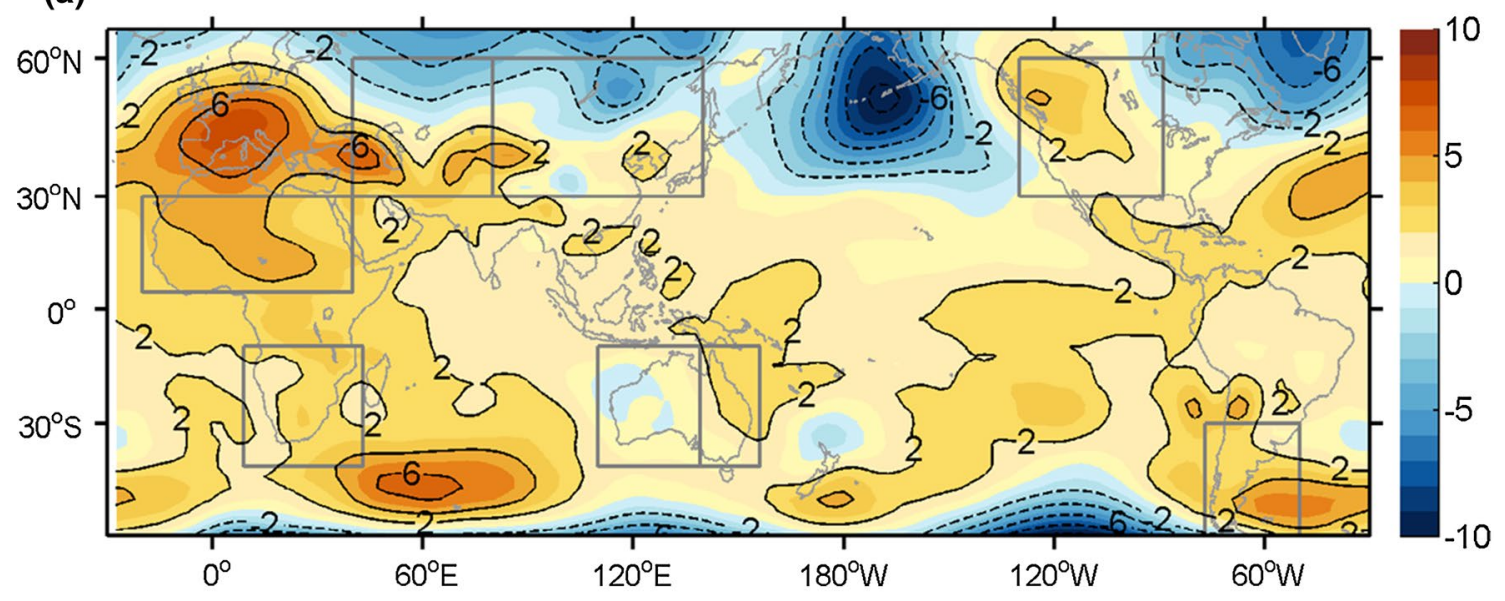

(b)

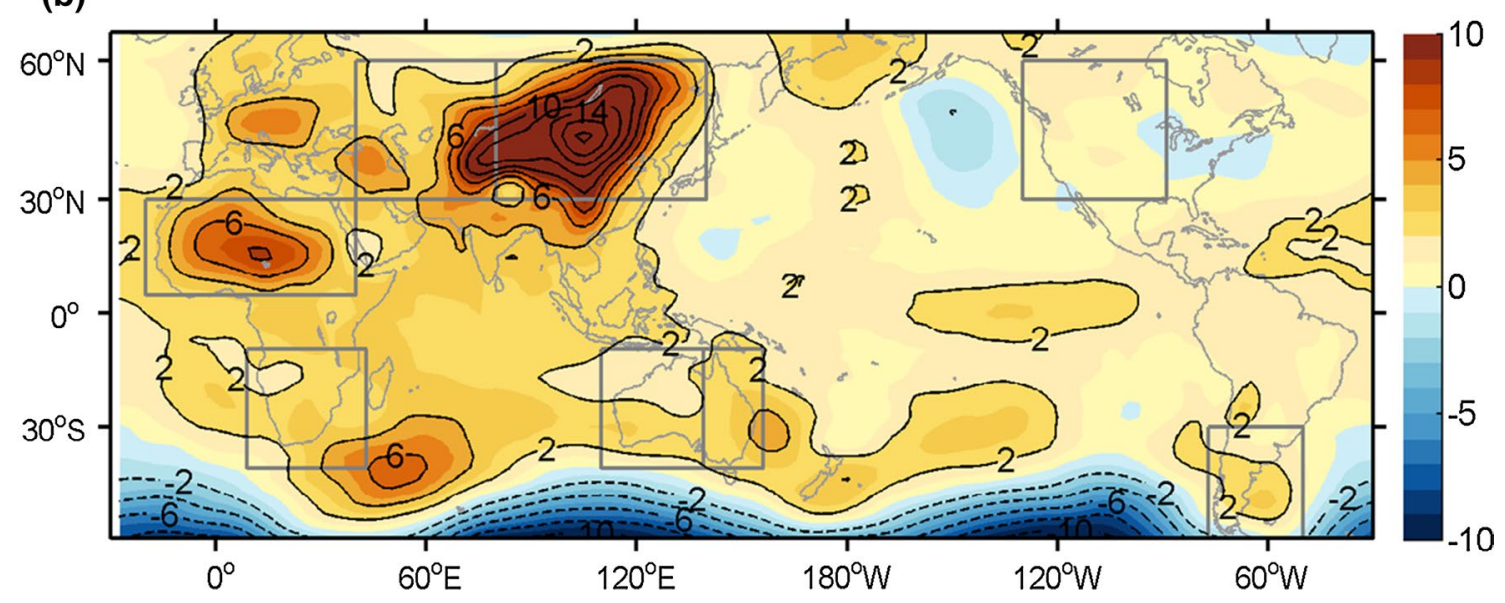

Fig. 9 Linear trends in the mean geopotential height $(1 \mathrm{gpm} /$ decade, interval $=2$ gpm/decade $)$ at $850 \mathrm{hPa}$ using the NCEP/NCAR re-analyses for $\mathbf{a}$ DJF and $\mathbf{b}$ JJA

regions (Fig. 8d-f). The increasing trend in the precipitation and significant decreasing trend in the PET contribute to an upward trend in the AI, which indicates that the climate became wetter in central/west Australia, even though the wetting trend is not significant. Similar results for the regionally averaged precipitation and PET show significant increases in the old and newly formed semi-arid regions over South America. The AI shows upward trends of 0.06 and 0.04 , which indicate that the semi-arid regions became wetter over the last 61 years in South America (figure not shown).

\section{Dynamics of climate change in semi-arid regions}

Semi-arid climate change may be caused by both globaland regional-scale factors. The global-scale factors include planetary-scale internal dynamical processes, SST anomalies, well-mixed greenhouse effects and external forcing.
However, the effects of these factors on climate change in semi-arid regions might vary by region. In this section, we discuss the causes of the different behaviors in semi-arid climate changes over the eight typical semi-arid regions via the effect of planetary-scale internal dynamical processes and atmospheric-ocean interactions.

First, the linear trend in the atmospheric circulations from the NCEP/NCAR re-analyses during the period of 1948-2008, including the geopotential heights (HGT) and winds at $850 \mathrm{hPa}$ are examined, as indicated in Figs. 9 and 10. Comparing the influences of the westerly circulation and monsoon circulation on semi-arid areas in North America and East Asia, North America is more strongly influenced by the westerly circulation, but East Asia is more strongly influenced by the monsoon circulation (Trenberth et al. 2000; Wang and Ding 2006). Under global warming, the temperature rise has not been evenly distributed over the globe; the North Pacific has cooled along $40^{\circ} \mathrm{N}$ (figure not shown; IPCC 2007), and the Aleutian Low has 

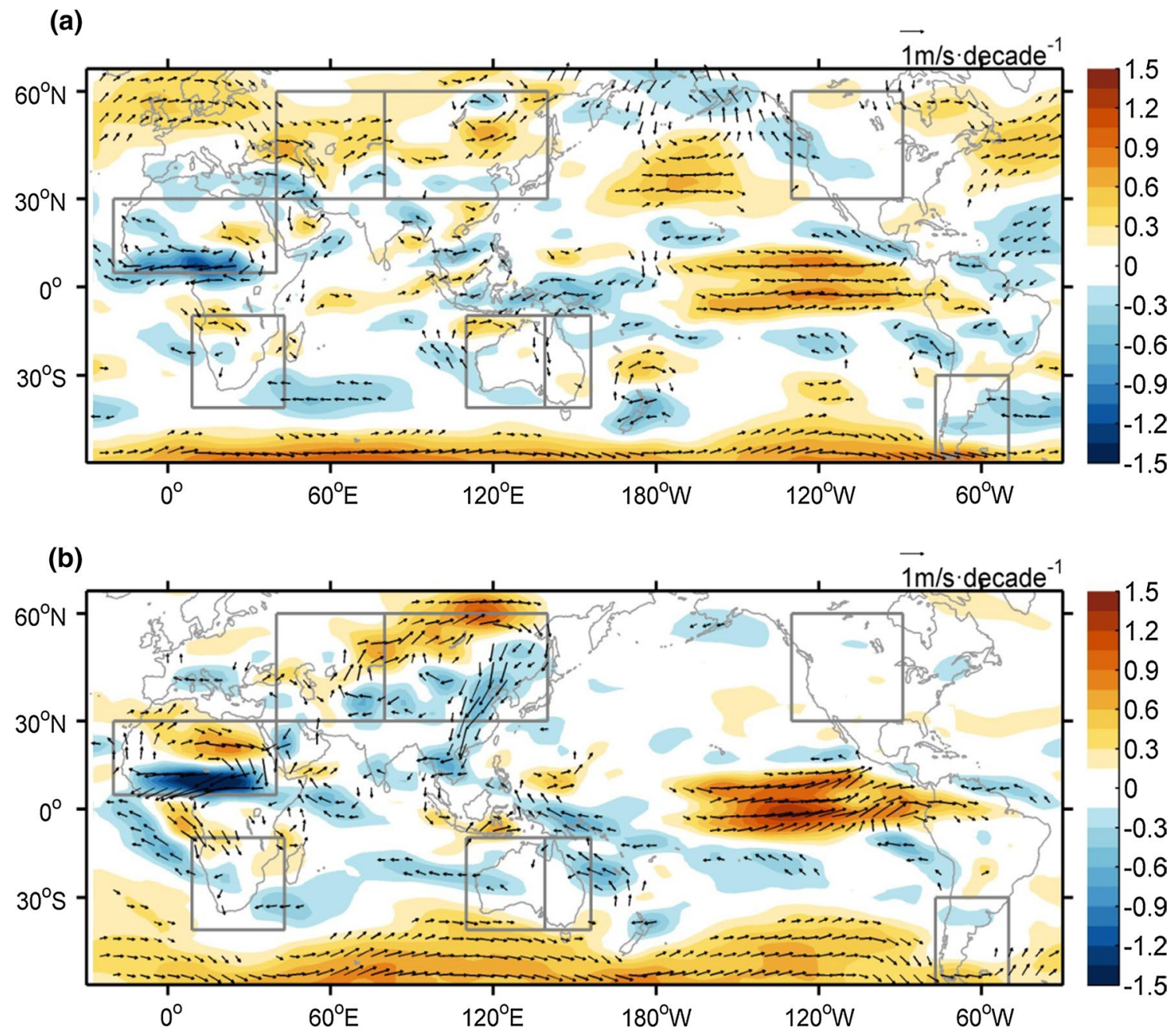

Fig. 10 Linear trends in the wind (vectors, $1 \mathrm{~m} / \mathrm{s}$ decade) and mean zonal wind (shading, $1 \mathrm{~m} / \mathrm{s} \mathrm{decade)} \mathrm{at} 850 \mathrm{hPa}$ using the NCEP/NCAR reanalyses in $\mathbf{a}$ DJF and b JJA

been deepening, particularly in winter (Fig. 9). This longterm strengthening of the Aleutian Low causes an increase in Western US cool-season precipitation (e.g. Huang et al. 2005; Dai 2013b), highly owing to the accelerated westerly along the southern flank of the deepened Aleutian Low (Fig. 10). This enhanced westerly favors substantially more moisture-rich air and storm tracks from Pacific to the west North America, thereby favoring precipitation and contributing to the wetting trend in this region. Additionally, warm Atlantic SSTs also influence the precipitation over the western US, particularly in summer (Kushnir et al. 2010; Feng et al. 2011), primarily by modulating the impact of the El Niño-Southern Oscillation (ENSO)-like SST forcing in the Pacific, which is comparatively weak (Mo et al. 2009). However, for the semi-arid region in East Asia, the climate is largely controlled by the Asia monsoon system, particularly the summer monsoon. As shown in Fig. 9b, almost all of East Asia is controlled by an anomalous high pressure center accompanied by anomalously strong northerlies along its eastern flank (Fig. 10b), implying the East Asian summer monsoon (EASM) is weakening (Fig. 11). This result is consistent with the previous studies (Xu et al. 2006; Zhu et al. 2012; Zuo et al. 2012). This is in related to a reduction in the meridional thermal gradients between Asian continent and adjacent oceans due to pronounced warming over the tropics (IPCC 2007; Ueda et al. 2006; He et al. 2014). Because the EASM is weakening, the moisture advected by the monsoon cannot reach the margin of semiarid area; thus, drying is induced over these regions. Overall, the two different circulation systems, i.e., the westerlies and the EASM, play decisive roles in the wetting of the semi-arid climate in North America and the drying in East Asia, respectively.

In contrast to East Asia, the moisture of Central Asia is primarily delivered by the prevailing westerlies in the midlatitudes (Chen et al. 2010). Because of the anomalous 
Fig. 11 The annual mean time series of the East Asia summer monsoon index. The black curves indicate the 11-year Gaussian-type filtered values, and the dashed lines denote the linear trend in the curves

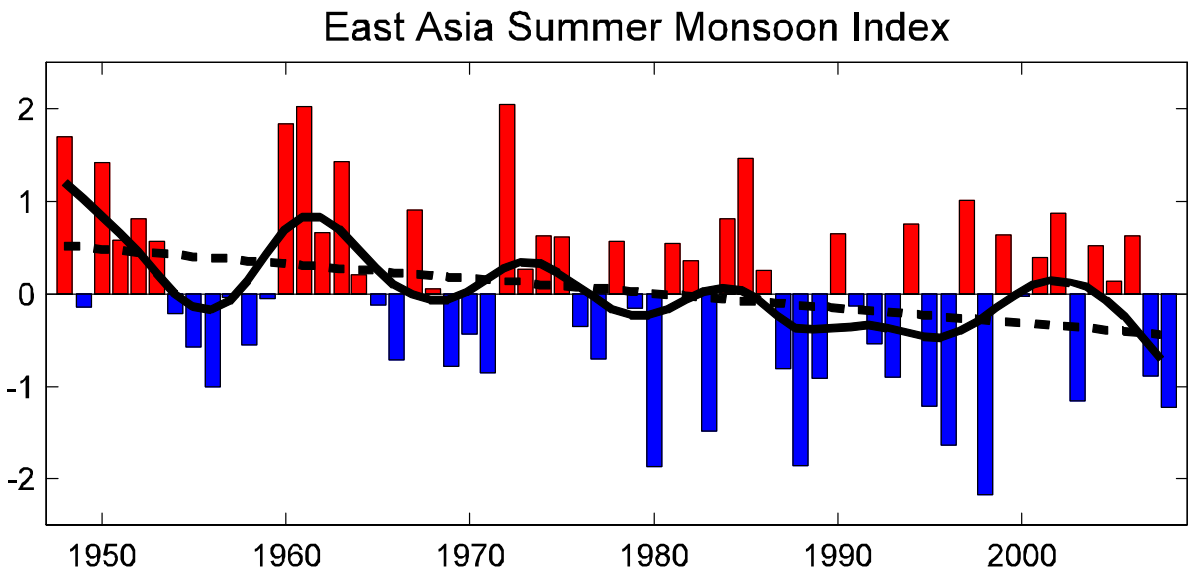

high pressure center over most of Asia (Fig. 9), anomalous easterlies exist to the south and anomalous westerlies exist to the north of Central Asia, implying that the prevailing westerlies are becoming stronger in the north and weaker in the south (Fig. 10). Similar circulation trend happens in boreal spring and autumn as well. These changes induce the wetting in the northernmost regions of Central Asia and the drying over most of the southern area, as indicated in Fig. 5b, whereas the semi-arid climate is drier, on average, across all of Central Asia, particularly under the influence of the pronounced warming in this region.

The climate over the semi-arid region in northern Africa is inextricably linked to the West African monsoon (WAM) system, which blows from the tropical Atlantic Ocean across the Sahel and brings rain to this region, primarily during the boreal summer (Nicholson 2013; Nicholson and Kim 1997). Many results with various atmospheric models forced by the long-term global sea surface temperature (SST) reveal that the oceans control the change in the precipitation in the African Sahel (Bader and Latif 2003; Giannini et al. 2003; Hagos and Cook 2008; Lu and Delworth 2005). Although warming of the tropical Indian Oceans is a non-negligible component of historical Sahelian drought (Bader and Latif 2003; Hagos and Cook 2008; Lu and Delworth 2005), the Atlantic Ocean SSTs played an important role in the recovering rainfall in the 1990s (Hagos and Cook 2008; Hoerling et al. 2006; Ting et al. 2009). As shown in Fig. 9b, an anomalously high pressure center occurs around the Sahel in the long-term trend, and the land-sea low-level pressure gradient is weakened, which drives a weaker monsoon flow and induces a drying trend in this semi-arid region.

The semi-arid region in southern Africa receives the most rainfall in the austral summer season, primarily due to the tropical-extratropical influences and associated convection, which are strongly influenced by the surrounding oceans, particularly the Indian Ocean. The Indian Ocean has warmed markedly since 1970 (IOCI 2002), accompanied with broad rising pressure trend over southern Africa. These changes in the SST and regional circulation inhibit convection and induce a drying trend over the semi-arid region in southern Africa. In addition, the rainfall in southern Africa is also affected by ENSO via the influence on the SST fluctuations in the western Indian Oceans, with drier than normal conditions during El Niño and wetter conditions during La Niña (Nicholson and Kim 1997; Richard et al. 2000; Mason 2001; Reason and Rouault 2002; Misra 2003; Kane 2009). During the last half of the 20th century, El Niño events strengthened, occurred more frequently, and had a more stable relationship with South Africa because of the increasing trend in the Pacific Decadal Oscillation (PDO) index, thereby worsening the semiarid climate over southern Africa.

The annual rainfall has changed significantly in recent decades in the semi-arid region of Australia. Precipitation has declined in east Australia but has shown a marked increasing trend in central/west Australia, mainly during the austral summer season (Wardle and Smith 2004; Shi et al. 2008). The marked changes over the Indian Ocean, particularly since 1970 , could trigger the overlying atmospheric circulation that generates anomalous ascending motion west of $140^{\circ} \mathrm{E}$ and anomalous subsidence east of $140^{\circ} \mathrm{E}$; these changes are responsible for the wetting over central/west Australia (promoting convection) and drying observed over east Australia (inhibiting convection) (Taschetto and England 2008; Li et al. 2012). In addition, an anomalous anticyclonic circulation at low levels in the east tends to weaken the easterlies from the tropical western Pacific, thus diminishing the transport of moisture and exacerbating the drying over east Australia. An anomalous cyclonic circulation over central/west Australia brings moist air to the northwest, leading to an increase in rainfall over the semi-arid region in central/west Australia (Fig. 9a). The drying trend over east Australia could be associated with ENSO (Taschetto and England 2008; Shi et al. 2008). In approximately 1976, the PDO entered a warm phase, 
with an increasing frequency of El Niño events and a drying trend over east Australia.

The semi-arid region in South America is located leeward of the Andes Mountains, which are oriented northsouth, and is strongly influenced by the typical westerly flow (Garreaud et al. 2013; Garreaud 2007; Parker et al. 2007). Most of the humid air masses transported by the westerlies from the Pacific are blocked by the Andes, and downslope subsidence dries the area east of the Andes via adiabatic warming (Paruelo et al. 1998; Garreaud et al. 2013). Therefore, the precipitation over the semi-arid region east of the Andes is strongly and negatively correlated with the 850-hPa zonal wind (Garreaud 2007; Garreaud et al. 2013). During the last six decades, re-analysis data suggested that an anomalously high pressure center existed over Patagonia (Fig. 9a, b), accompanied by anomalous easterlies (westerlies) along the northern (southern) flank (Fig. 10a, b). This high pressure trend is similar to the result shown by Thompson and Wallace (2000), who indicated that these results to be at least qualitatively reliable despite concerns about the reliability of the NCEP-NCAR reanalysis over this region (e.g. Randel and Wu 1999; Marshall 2003). Accordingly, the westerly flow tended to decrease in the mid-latitudes (approximately $45^{\circ} \mathrm{S}$ ); therefore, the anomalous onshore winds bring additional moisture and favoring a wetting trend in the semi-arid region to the east of the Andes.

\section{Conclusions and discussion}

Of all subtypes of global drylands, semi-arid regions have the largest area, which accounts for more than one-third of the total dryland area. The largest expansion of drylands also occurs in semi-arid regions, which account for half of the total dryland expansion. Globally, semi-arid regions have expanded over the last 61 years (1948-2008), and the area during 1990-2004 is $1.6 \times 10^{6} \mathrm{~km}^{2}$ (or $7 \%$ ) larger than that during 1948-1962. The expansion of semi-arid regions across the continents in the Eastern Hemisphere accounts for $75 \%$ of the total expanded semi-arid regions $\left(1.6 \times 10^{6} \mathrm{~km}^{2}\right)$ than that of $25 \%$ across the American continents. Although expansions of semi-arid regions occur in both areas, the shifting patterns of the expansion are different. The newly formed semi-arid regions are shifted from arid regions, where the climate becomes wetter, over the American continents. Conversely, in the continents of the Eastern Hemisphere, the expansion of semi-arid regions replaces the sub-humid/humid regions, where the climate becomes drier. In all eight semi-arid regions considered, five of them become drier, but another three, as North America, South America and central/west Australia, become wetter. The rates of change in precipitation, PET and $\mathrm{AI}$ in the newly formed semi-arid regions are much larger than those in the old semi-arid regions in the drying semi-arid regions. However, the precipitation, PET and AI show similar trends, with only slight differences between the newly formed and old areas in the wetting semi-arid regions that transitioned from drier climate types.

Notably, two temperate semi-arid regions in North America and East Asia show different climatic patterns. The distinct behaviors of the old and newly established semi-arid regions in North America and East Asia reveal the different responses of semi-arid areas to the decadal variability in the westerlies and monsoon systems under global warming. The climate change in the drying semiarid region over East Asia is mainly dominated by a weaker East Asian summer monsoon, whereas the wetting semiarid regions over North America are mainly controlled by enhanced westerlies, which are related to the reduced ocean-land temperature gradient under global warming ( $\mathrm{He}$ et al. 2014).

Furthermore, the decadal variations and long-term trends in sea surface temperatures (SSTs) of the world oceans also play a crucial role in the widespread drying over semi-arid regions by providing boundary forcing, as well as initiating and sustaining particular circulation anomalies in the atmosphere at the corresponding time scales (Kushnir et al. 2002; Alexander 2013). Evidence indicates that the widespread drying that has occurred over the decades in semiarid regions is also controlled by atmospheric-ocean interactions (Huang et al. 1998; Wang et al. 2014). Studies using atmospheric models forced by long-term SSTs support the claim of a controlling role of the oceans on the climate of the semi-arid region in the Sahel (Bader and Latif 2003; Giannini et al. 2003; Hoerling et al. 2006; Lu 2009; Lu and Delworth 2005) and other extra-tropical semi-arid regions (McCabe et al. 2008; Méndez and Magaña 2010). Warming of the tropical oceans is a non-negligible component of historical Sahelian droughts (Hagos and Cook 2008; Ting et al. 2009), and the current recovery can be attributed to the variability in the Atlantic Ocean (Hoerling et al. 2006; Ting et al. 2009). Warming in the tropical Pacific could weaken summer monsoons and thus drier conditions in eastern China (Li et al. 2010; Zhou et al. 2009).

In addition to the effect of the oceans, previous studies also emphasized that the interaction between land surfaces (land use and land cover change) and the atmosphere is critical for drying trends in semi-arid regions (Huang et al. 2008; Guan et al. 2009; Wang et al. 2010). A positive feedback process was proposed by Otterman (1974) and explained by (Charney 1975) as follows: bare soil reduces the net radiation at the surface, thus creating evaporation and moist static energy declines, which induce drier and warmer conditions (Nicholson 2000; Xue 1996; Xue and Shukla 1993; Zeng et al. 1999). Increased local 
anthropogenic dust aerosols associated with human activities, such as agriculture and industrial activities might play an important role in the drying trends over the semiarid regions (Cook et al. 2009; Su et al. 2008; Huang et al. 2010, 2011, 2014; Mulitza et al. 2010; Wang et al. 2013). Thus, human activities can also lead to significant change over semi-arid regions. An attribution of human-induced land use change is needed to examine the anthropogenic contribution. Effort has been made to discriminate between climate and human-induced dryland changes (Evans and Geerken 2004; Omuto et al. 2010; Wessels et al. 2007). However, these studies are mainly case studies that require high-quality satellite observations (e.g., normalized difference vegetation index data (NDVI)). Therefore, the change in global human-induced semi-arid regions requires further research.

All of the factors discussed contribute to the climate change observed over semi-arid regions. The drying or wetting trends in semi-arid regions might be dominated by SST anomalies or by local land surface processes due to human activities and global warming. Further studies are needed to clarify the contributions of these factors.

Acknowledgments This work was jointly supported by the National Basic Research Program of China (2012CB955301), National Science Foundation of China (41175134 and 41305060), the Fundamental Research Funds for the Central Universities (lzujbky-2015-ct03), and China 111 project (B13045).

Open Access This article is distributed under the terms of the Creative Commons Attribution 4.0 International License (http://creativecommons.org/licenses/by/4.0/), which permits unrestricted use, distribution, and reproduction in any medium, provided you give appropriate credit to the original author(s) and the source, provide a link to the Creative Commons license, and indicate if changes were made.

\section{References}

Allen R, Pereira L, Raes D, Smith M (1998) Crop evapotranspiration - guidelines for computing crop water requirements. FAO Irrigation and Drainage Paper 56. FAO, Rome

Alexander M (2013) Extratropical air-sea interaction, sea surface temperature variability, and the Pacific decadal oscillation. In: Sun D, Bryan F (eds) Climate dynamics: why does climate vary? American Geophysical Union, Washington, pp 123-148

Bader J, Latif M (2003) The impact of decadal-scale Indian Ocean sea surface temperature anomalies on Sahelian rainfall and the North Atlantic Oscillation. Geophys Res Lett 30(22):2169. doi: 10.1029/2003GL018426

Bounoua L, Safia A, Masek J, Peters-Lidard C, Imhoff M (2009) Impact of urban growth on surface climate: a case study in Oran, Algeria. J Appl Meteorol 48(2):217-231

Charney J (1975) Dynamics of deserts and drought in the Sahel. Q J R Meteorol Soc 101(428):193-202

Chen M, Xie P, Janowiak JE, Arkin PA (2002) Global land precipitation: a 50-yr monthly analysis based on gauge observations. J Hydrometeorol 3:249-266

Chen F, Chen J, Holmes J, Boomer I, Austin P, Gates J, Wang N, Brooks S, Zhang J (2010) Moisture changes over the last millennium in arid central Asia: a review, synthesis and comparison with monsoon region. Quat Sci Rev 29(7-8):1055-1068

Chou C, Neelin J, Chen C, Tu J (2009) Evaluating the "rich-getricher" mechanism in tropical precipitation change under global warming. J Clim 22(8):1982-2004

Compo GP, Whitaker JS, Sardeshmukh PD, Matsui N, Allan RJ, Yin X, Gleason BE, Vose RS, Rutledge G, Bessemoulin P, Brönnimann S, Brunet M, Crouthamel RI, Grant AN, Groisman PY, Jones PD, Kruk MC, Kruger AC, Marshall GJ, Maugeri M, Mok HY, Nordli $\varnothing$, Ross TF, Trigo RM, Wang XL, Woodruff SD, Worley SJ (2011) The twentieth century reanalysis project. Q J Roy Meteor Soc 137(654):1-28. doi:10.1002/qj.776

Cook BI, Miller RL, Seager R (2009) Amplification of the North American "Dust Bowl" drought through human-induced land degradation. Proc Natl Acad Sci USA 106(13):4997-5001

Dai A (2013a) Increasing drought under global warming in observations and models. Nat Clim Change 3(1):52-58

Dai A (2013b) The influence of the inter-decadal Pacific oscillation on US precipitation during 1923-2010. Clim Dyn 41(3-4):633-646

Dai A, Lamb PJ, Trenberth KE, Hulme M, Jones PD, Xie P (2004) The recent Sahel drought is real. Int J Climatol 24(11):1323-1331

Donohue RJ, McVicar TR, Roderick ML (2010) Assessing the ability of potential evaporation formulations to capture the dynamics in evaporative demand within a changing climate. J Hydrol 386(1):186-197

Dregne H (2002) Land degradation in the drylands. Arid Land Res Manag 16(2):99-132

Evans J, Geerken R (2004) Discrimination between climate and humaninduced dryland degradation. J Arid Environ 57(4):535-554

Fan Y, Van den Dool H (2008) A global monthly land surface air temperature analysis for 1948-present. J Geophys Res Atmos (1984-2012) 113(D1):D01103. doi:10.1029/2007JD008470

Feddema J (2005) A revised Thornthwaite-type global climate classification. Phys Geogr 26(6):442-466

Feng S, Fu Q (2013) Expansion of global drylands under a warming climate. Atmos Chem Phys 13(19):10081-10094

Feng S, Hu Q, Oglesby R (2011) Influence of Atlantic sea surface temperatures on persistent drought in North America. Clim Dyn 37:569-586

Feng S, Hu Q, Huang W, Ho C, Li R, Tang Z (2014) Projected climate regime shift under future global warming from multi-model, multiscenario CMIP5 simulations. Global Planet Change 112:41-52

Fricke K, Sterr T, Bubenzer O, Eitel B (2009) The oasis as a megacity: Urumqi's fast urbanisation in a semiarid environment. Erde 140(4):449-463

Gao Q, Kang M, Xu H, Jiang Y, Yang J (2010) Optimization of land use structure and spatial pattern for the semi-arid loess hillygully region in China. Catena 81(3):196-202

Garreaud R (2007) Precipitation and circulation covariability in the extratropics. J Clim 20(18):4789-4797. doi:10.1175/JCLI4257.1

Garreaud R, Lopez P, Minvielle M, Rojas M (2013) Large-scale control on the Patagonian climate. J Clim 26(1):215-230. doi:10.1175/jcli-d-12-00001.1

Geiger R (1954) Klassifikation der Klimate nach W. Köppen. In: Landolt-Börnstein-Zahlenwerte und Funktionen aus Physik, Chemie, Astronomie, Geophysik und Technik, vol 3. Springer, Berlin, pp 603-607

Georgescu M, Miguez-Macho G, Steyaert L, Weaver C (2009) Climatic effects of 30 years of landscape change over the Greater Phoenix, Arizona, region: 1. Surface energy budget changes. J Geophys Res Atmos (1984-2012) 114(D5):D05110. doi:10.10 29/2008JD010745

Giannini A, Saravanan R, Chang P (2003) Oceanic forcing of Sahel rainfall on interannual to interdecadal time scales. Science 302(5647):1027-1030 
Greve P, Orlowsky B, Mueller B, Sheffield J, Reichstein M, Seneviratne SI (2014) Global assessment of trends in wetting and drying over land. Nat Geosci 7(10):716-721

Guan X, Huang J, Guo N, Bi J, Wang G (2009) Variability of soil moisture and its relationship with surface albedo and soil thermal parameters over the Loess Plateau. Adv Atmos Sci 26(4):692-700. doi:10.1007/s00376-009-8198-0

Hagos SM, Cook KH (2008) Ocean warming and late-twentieth-century Sahel drought and recovery. J Clim 21(15):3797-3814

Hamon WR (1963) Computation of direct runoff amounts from storm rainfall. Int Assoc Sci Hydrol Pub 63:52-62

Hargreaves G, Samani Z (1985) Reference crop evapotranspiration from temperature. Appl Eng Agric 1:96-99

He Y, Huang J, Ji M (2014) Impact of land-sea thermal contrast on interdecadal variation in circulation and blocking. Clim Dyn. doi:10.1007/s00382-00014-02103-y

Held IM, Soden BJ (2006) Robust responses of the hydrological cycle to global warming. J Clim 19(21):5686-5699

Hobbins M, Wood A, Struebel D, Werner K (2012) What drives the variability of evaporative demand across the conterminous United States? J Hydrometeorol 13:1195-1214

Hoerling M, Hurrell J, Eischeid J, Phillips A (2006) Detection and attribution of twentieth-century northern and southern African rainfall change. J Clim 19:3989-4008

Huang J, Higuchi K, Shabbar A (1998) The relationship between the North Atlantic oscillation and El Niño-Southern oscillation. Geophys Res Lett 25:2707-2710

Huang H, Seager R, Kushnir Y (2005) The 1976/77 transition in precipitation over the Americas and the influence of tropical sea surface temperature. Clim Dyn 24(7-8):721-740

Huang J, Zhang W, Zuo J, Bi J, Shi J, Wang X, Chang Z, Huang Z, Yang S, Zhang B, Wang G, Feng G, Yuan J, Zhang L, Zuo H, Wang S, Fu C, Chou J (2008) An overview of the semi-arid climate and environment research observatory over the Loess Plateau. Adv Atmos Sci 25(6):1-16

Huang J, Minnis P, Yan H, Yi Y, Chen B, Zhang L, Ayers J (2010) Dust aerosol effect on semi-arid climate over Northwest China detected from A-Train satellite measurements. Atmos Chem Phys 10(14):6863-6872

Huang J, Fu Q, Zhang W, Wang X, Zhang R, Ye H, Warren S (2011) Dust and black carbon in seasonal snow across northern China. Bull Am Meteorol Soc 92(2):175-181. doi:10.1175/2010BAMS3064.1

Huang J, Guan X, Ji F (2012) Enhanced cold-season warming in semi-arid regions. Atmos Chem Phys 12(12):5391-5398

Huang J, Wang T, Wang W, Li Z, Yan H (2014) Climate effects of dust aerosols over East Asian arid and semiarid regions. J Geophys Res Atmos 119:11398-11416. doi:10.1002/2014JD021796

Hulme M, Doherty R, Ngara T, New M, Lister D (2001) African climate change: 1900-2100. Clim Res 17(2):145-168

IOCI (2002) Climate variability and change in southwest Western Australia. Technical report, Indian Ocean Climate Initiative Panel, Perth, p 34

IPCC (2007) Climate change 2007: the physical science basis. In: Solomon S, Qin D, Manning M, Chen Z, Marquis M, Averyt K, Tignor M, Miller H (eds) Contribution of Working Group I to the fourth assessment report of the Intergovernmental Panel on Climate Change. Cambridge University Press, Cambridge

Ji F, Wu Z, Huang J, Eric P (2014) Evolution of land surface air temperature trend. Nat Clim Change. doi:10.1038/nclimate2223

Kalnay E, Kanamitsu M, Kistler R, Collins W, Deaven D, Gandin L, Iredell M, Saha S, White G, Woollen J, Zhu Y, Leetmaa A, Reynolds R, Chelliah M, Ebisuzaki W, Higgins W, Janowiak J, Mo K, Ropelewski C, Wang J, Jenne R, Joseph D (1996) The NCEP/NCAR 40-Year Reanalysis Project. Bull Am Meteorol Soc 77:437-471
Kane R (2009) Periodicities, ENSO effects and trends of some South African rainfall series-an update. S Afr J Sci 105(5-6):199-207

Köppen W (1884): Die Wärmezonen der Erde, nach der Dauer der heissen, gemässigten und kalten Zeit und nach der Wirkung der Wärme auf die organische Welt betrachtet (The thermal zones of the earth according to the duration of hot, moderate and cold periods and to the impact of heat on the organic world). -Meteorol. Z. 1, 215-226. (trans, ed: Volken E, Brönnimann S. Meteorol. Z. 20 (2011), 351-360)

Köppen W (1936) Das geographische System der Klimate. In: Koppen W, Geiger R (eds) Handbuch der Klimatologie, vol 1, GebrBorntrager, Berlin, pp 1-44

Kottek M, Grieser J, Beck C, Rudolf B, Rubel F (2006) World map of the Koppen-Geiger climate classification updated. Meteorol Z 15(3):259-263

Kushnir Y, Robinson W, Bladé I, Hall N, Peng S, Sutton R (2002) Atmospheric GCM response to extratropical SST anomalies: synthesis and evaluation. J Clim 15:2233-2256

Kushnir Y, Seager R, Ting M, Naik N, Nakamura J (2010) Mechanisms of tropical Atlantic SST influence on North American precipitation variability. J Clim 23:5610-5628

Legates DR, Willmott CJ (1990a) Mean seasonal and spatial variability in gauge-corrected, global precipitation. Int J Climatol 10(2):111-127

Legates DR, Willmott CJ (1990b) Mean seasonal and spatial variability in global surface air temperature. Theor Appl Climatol 41(1-2):11-21

Li J, Zeng Q (2002) A unified monsoon index. Geophys Res Lett 29(8):1274. doi:10.1029/2001GL013874

Li H, Dai A, Zhou T, Lu J (2010) Responses of East Asian summer monsoon to historical SST and atmospheric forcing during 1950-2000. Clim Dyn 34(4):501-514

Li A, Wu J, Huang J (2012) Distinguishing between human-induced and climate-driven vegetation changes: a critical application of RESTREND in inner Mongolia. Landsc Ecol 27(7):969-982

Liu C, Xia J (2004) Water problems and hydrological research in the Yellow River and the Huai and Hai River basins of China. Hydrol Process 18(12):2197-2210

Liu H, Yin Y, Tian Y, Ren J, Wang H (2008) Climatic and anthropogenic controls of topsoil features in the semi-arid East Asian steppe. Geophys Res Lett 35(4):L04401. doi:10.1029/200 $7 \mathrm{GL} 032980$

Lu J (2009) The dynamics of the Indian Ocean sea surface temperature forcing of Sahel drought. Clim Dyn 33(4):445-460

Lu J, Delworth TL (2005) Oceanic forcing of the late 20th century Sahel drought. Geophys Res Lett 32(22):L22706. doi:10. 1029/2005GL023316

Mabbutt JA (1979) Desert landforms. MIT, Cambridge, p 340

Makkink G (1957) Testing the Penman formula by means of Lysimeters. J Inst of Water Eng 11:277-288

Marshall G (2003) Trends in the Southern Annular Mode from Observations and Reanalyses. J Clim 16:4134-4143

Mason S (2001) El Niño, climate change, and Southern African climate. Environmetrics 12:327-345

McAfee S (2013) Methodological differences in projected potential evapotranspiration. Clim Change 120:915-930

McCabe GJ, Betancourt JL, Gray ST, Palecki MA, Hidalgo HG (2008) Associations of multi-decadal sea-surface temperature variability with US drought. Quat Int 188(1):31-40

McVicar TR, Roderick ML, Donohue RJ, Li LT, Van Niel TG, Thomas A, Grieser J, Jhajharia D, Himri Y, Mahowald NM (2012) Global review and synthesis of trends in observed terrestrial near-surface wind speeds: implications for evaporation. J Hydrol 416:182-205 
Méndez M, Magaña V (2010) Regional aspects of prolonged meteorological droughts over Mexico and Central America. J Clim 23(5): 1175-1188

Middleton N, Thomas D (1997) World atlas of desertification, 2nd edn. Arnold, a member of the Hodder Headline Group, London

Misra V (2003) The influence of Pacific SST variability on the precipitation over southern Africa. J Clim 16:2408-2418

Mitchell T, Jones PD (2005) An improved method of constructing a database of monthly climate observations and associated highresolution grids. Int J Climatol 25(6):693-712

Mo K, Schemm J, Yoo S (2009) Influence of ENSO and the Atlantic multidecadal oscillation on drought over the United States. J Clima 22:5962-5982

Monteith J (1981) Evaporation and surface temperature. Q J Roy Meteor Soc 107(451):1-27

Mulitza S, Heslop D, Pittauerova D, Fischer HW, Meyer I, Stuut J-B, Zabel M, Mollenhauer G, Collins JA, Kuhnert H (2010) Increase in African dust flux at the onset of commercial agriculture in the Sahel region. Nature 466(7303):226-228

Nicholson S (2000) Land surface processes and Sahel climate. Rev Geophys 38(1):117-139

Nicholson S (2013) The West African Sahel: a review of recent studies on the rainfall regime and its interannual variability. ISRN Meteorol 2013:1-32

Nicholson S, Kim J (1997) The relationship of the El Niño Southern oscillation to African rainfall. Int J Climatol 17:117-135

Omuto C, Vargas R, Alim M, Paron P (2010) Mixed-effects modelling of time series NDVI-rainfall relationship for detecting humaninduced loss of vegetation cover in drylands. J Arid Environ 74(11):1552-1563

Otterman J (1974) Baring high-albedo soils by overgrazing - a hypothesized desertification mechanism. Science 186(4163):531-533

Parker D, Folland C, Scaife A, Knight J, Colman A, Baines P, Dong B (2007) Decadal to multidecadal variability and the climate change background. J Geophys Res. doi:10.1029/2007jd008411

Paruelo JM, Beltrán Adriana, Jobbágy Esteban, Sala Osvaldo E, Golluscio RA (1998) The climate of Patagonia: general patterns and controls on biotic processes. Ecol Austral 8:85-101

Peel M, Finlayson B, McMahon T (2007) Updated world map of the Köppen-Geiger climate classification. Hydrol Earth Syst Sci 11:1633-1644

Penman HL (1948) Natural evaporation from open water, bare soil and grass. Proc R Soc Lond A 193(1032):120-145

Priestley C, Taylor R (1972) On the assessment of surface heat flux and evaporation using large scale parameters. Mon Weath Rev 100:81-92

Randel W, Wu F (1999) Cooling of the Arctic and Antarctic polar stratospheres due to ozone depletion. J Clim 12:1467-1479

Reason C, Rouault C (2002) ENSO-like decadal variability and South African rainfall. Geophys Res Lett 29:1638. doi:10.1029/200 2GL014663

Richard Y, Trzaska S, Roucou P, Rouault M (2000) Modification of the Southern African rainfall variability/El Niño southern oscillation relationship. Clim Dyn 16:883-895

Rodell M, Houser P, Jambor U, Gottschalck J, Mitchell K, Meng C, Arsenault K, Cosgrove B, Radakovich J, Bosilovich M (2004) The global land data assimilation system. B Am Meteorol Soc 85(3):381-394

Rotenberg E, Yakir D (2010) Contribution of semi-arid forests to the climate system. Science 327(5964):451-454

Safriel U, Adeel Z (2005) Dryland systems. In: Hassan R, Scholes R, Ash $\mathrm{N}$ (eds) Ecosystems and human well-being, current state and trends, vol 1. Island Press, Washington, pp 625-658

Scanlon BR, Keese KE, Flint AL, Flint LE, Gaye CB, Edmunds WM, Simmers I (2006) Global synthesis of groundwater recharge in semiarid and arid regions. Hydrol Process 20(15):3335-3370
Schiemann R, Luthi D, Vidale P, Schar C (2008) The precipitation climate of Central Asia-intercomparison of observational and numerical data sources in a remote semiarid region. Int J Climatol 28:295-314

Schwinning S, Sala OE, Loik ME, Ehleringer JR (2004) Thresholds, memory, and seasonality: understanding pulse dynamics in arid/ semi-arid ecosystems. Oecologia 141(2):191-193

Seager R, Naik N, Vecchi GA (2010) Thermodynamic and dynamic mechanisms for large-scale changes in the hydrological cycle in response to global warming. J Clim 23(17):4651-4668

Shaw S, Riha S (2011) Assessing temperature-based PET equations under a changing climate in temperate, deciduous forests. Hydrol Process 25:1466-1478

Sheffield J, Goteti G, Wood E (2006) Development of a 50-year highresolution global dataset of meteorological forcings for land surface modeling. J Clim 19(13):3088-3111

Sheffield J, Wood EF, Roderick ML (2012) Little change in global drought over the past 60 years. Nature 491(7424):435-438

Shi G, Cai W, Cowan T, Ribbe J, Rotstayn L, Dix M (2008) Variability and trend over the northwest Western Australian rainfall: observations and coupled climate modeling. J Clim 21:2938-2959

Su J, Huang J, Fu Q, Minnis P, Ge J, Bi J (2008) Estimation of Asian dust aerosol effect on cloud radiation forcing using Fu-Liou radiative model and CERES measurements. Atmos Chem Phys 8(10):2763-2771

Taschetto A, England M (2008) An analysis of late 20th century trends in Australian rainfall. Int J Climatol 29:791-807

Thomas D (2011) Arid zone geomorphology: process, form and change in drylands, 3rd edn. Wiley-Blackwell, xxiv

Thompson D, Wallace JM (2000) Annular modes in the extratropical circulation. Part I: month-to-month variability. J Clim 13:1000-1016

Thornthwaite CW (1948) An approach toward a rational classification of climate. Geogr Rev 38(1):55-94

Ting M, Kushnir Y, Seager R, Li C (2009) Forced and internal twentieth-century SST trends in the North Atlantic. J Clim 22(6):1469-1481

Trenberth KE, Stepaniak DP, Caron JM (2000) The global monsoon as seen through the divergent atmospheric circulation. J Climate 13(22):3969-3993

Trewartha G, Horn L (1980) An introduction to climate, 5th edn. McGraw-Hill, New York, p 437

Turc L (1961) Evaluation de besoins en eau d'irrigation, ET potentielle. Ann Agron 12:13-49

Ueda H, Iwai A, Kuwako K, Hori M (2006) Impact of anthropogenic forcing on the Asian summer monsoon as simulated by eight GCMs. Geophys Res Lett 33:L06703. doi:10.1029/2005GL025336

Wang B, Ding Q (2006) Changes in global monsoon precipitation over the past 56 years. Geophys Res Lett 33(6):L06711. doi:10. 1029/2005GL025347

Wang K, Dickinson R (2012) A review of global terrestrial evapotranspiration: observation, modeling, climatology, and climatic variability. Rev Geophys 50:RG2005. doi:10.1029/2011RG000373

Wang G, Huang J, Guo W, Zuo J, Wang J, Bi J, Huang Z, Shi J (2010) Observation analysis of land-atmosphere interactions over the Loess Plateau of northwest China. J Geophys Res 115:D00K17. doi:10.1029/2009JD013372

Wang X, Doherty S, Huang J (2013) Black carbon and other lightabsorbing impurities in snow across Northern China. J Geophys Res Atmos 118:1471-1492

Wang S, Huang J, He Y, Guan Y (2014) Combined effects of the Pacific decadal oscillation and El Nino-southern oscillation on global land dry-wet changes. Sci Rep 4:6651. doi:10.1038/ srep06651

Wardle R, Smith I (2004) Modeled response of the Australian monsoon to changes in land surface temperatures. Geophys Res Lett 31:L16205. doi:10.1029/2004GL020157 
Wessels K, Prince S, Malherbe J, Small J, Frost P, VanZyl D (2007) Can human-induced land degradation be distinguished from the effects of rainfall variability? A case study in South Africa. J Arid Environ 68(2):271-297

Xu M, Chang C, Fu C, Qi Y, Robock A, Robinson D, Zhang H (2006) Steady decline of east Asian monsoon winds, 1969-2000: evidence from direct ground measurements of wind speed. J Geophys Res Atmos. doi:10.1029/2006JD007337

Xu Y, B-s Tang, Chan EH (2011) State-led land requisition and transformation of rural villages in transitional China. Habitat International 35(1):57-65

Xue Y (1996) The impact of desertification in the Mongolian and the Inner Mongolian grassland on the regional climate. J Clim 9(9):2173-2189

Xue Y, Shukla J (1993) The influence of land surface properties on Sahel climate. Part 1: desertification. J Clim 6(12):2232-2245
Zeng N, Neelin JD, Lau K-M, Tucker CJ (1999) Enhancement of interdecadal climate variability in the Sahel by vegetation interaction. Science 286(5444):1537-1540

Zhou T, Gong D, Li J, Li B (2009) Detecting and understanding the multi-decadal variability of the East Asian summer monsoonrecent progress and state of affairs. Meteorol Z 18(4):455-467

Zhu C, Wang B, Qian W, Zhang B (2012) Recent weakening of northern East Asian summer monsoon: a possible response to global warming. Geophys Res Lett. doi:10.1029/2012GL051155

Zuo Z, Yang S, Kumar A, Zhang R, Xue Y, Jha B (2012) Role of thermal condition over Asia in the weakening Asian summer monsoon under global warming background. J Clim 25(9):3431-3436 